\title{
0 surto de peste suína africana ocorrido em 1978 no município de Paracambi, Rio de Janeiro ${ }^{1}$
}

\author{
Carlos Hubinger Tokarnia² ${ }^{2}$ Paulo Vargas Peixoto ${ }^{2}$, Jürgen Döbereiner ${ }^{3}$, Severo \\ Sales de Barros $^{4}$ e Franklin Riet-Correa ${ }^{5}$
}

\begin{abstract}
Tokarnia C.H., Peixoto P.V., Döbereiner J., Barros S.S. \& Riet-Correa F. 2004. [The outbreak of African swine fever which ocurred in 1978 in the county of Paracambi, Rio de Janeiro, Brazil.] O surto de peste suína africana ocorrido em 1978 no município de Paracambi, Rio de Janeiro. Pesquisa Veterinária Brasileira 24(4):223-238. Projeto Sanidade Animal Embrapa/UFRRJ, Km 47, Seropédica, RJ 23890-000, Brazil. E-mail: tokarnia@ufrrj.br

Due to doubts which still persist 25 years after the outbreak of African swine fever (ASF) which ocurred in the county of Paracambi, Rio de Janeiro, Brazil, in 1978, the results obtained through the studies to establish and confirm the diagnosis are presented. These include data on the epidemiology, clinic-pathological aspects, bacteriological, virological and ultramicroscopic examinations, the experimental reproduction of the disease and cross immunity tests with classical swine fever virus performed in Brazil, and on the confirmation with isolation of the virus and determination of its identity at the Plum Island Animal Disease Center, New York, USA. The pigs of the affected herd had been fed untreated remains of meals from airplanes of international lines flying to Brazil from Portugal and Spain where ASF was occurring at the time. According to publication by the Ministry of Agriculture, after the diagnosis of the outbreak of ASF described in this paper, 223 additional outbreaks were reported in Brazil between 1978 and 1979, in all the Brazilian regions (North, Northeast, Central-West, Southeast and South). Further outbreaks were reported in 1981, but their number is not known. The last case was reported to have occurred on November 15, 1981, and on December 5, 1984, Brazil was declared free of ASF. For the diagnosis of ASF 54,002 samples were examined by the Department of Virology of the Institute of Microbiology, Federal University of Rio de Janeiro, from 1978 to 1981, by the techniques of haemadsorption in leucocyte cultures (HAd), direct immunoflorescence in tissue sections (FATS), direct immunoflorescence in cell cultures (FATCC), immuno-electro-osmophoresis (IEOP) and indirect immunoflorescence assay (IIF). Only 4 samples were positive with the FATCC procedure. This is the only technique which includes virus isolation; the origin of these positive samples was not reported, but probably they were from the Paracambi outbreak.

From other suspected outbreaks of ASF in Brazil there is no information on the isolation and characterization of the virus isolates. Likewise there is no information available about the epidemiology, clinical signs, and pathology of suspected ASF in other outbreaks. The analysis of all published data on this matter in Brazil, the possibility of false-positive results, the lack of information about isolation and characterization of the virus, as well as the lack of epidemiological, clinical and pathological data of these other supposed outbreacs of ASF strongly suggest that the outbreak of Paracambi was the only occurrence of ASF in Brazil, confirmed by the isolation, identification of the virus, and the determination of its pathogenicity, and that ASF occurred and maintained itself confined to this area probably due to the early diagnosis and the rapid application of efficient control measures by the Brazilian authorities; the slaughter of the animals in the outbreak of Paracambi started as soon as 10 days after the first death, 3 days after the presumptive diagnosis.
\end{abstract}

INDEX TERMS: African swine fever, Brazil, pathology, experimental reproduction.

\footnotetext{
${ }^{1}$ Recebido em 26 de março de 2004.

Aceito para publicação em 8 de dezembro de 2004 .

2 Depto Nutrição Animal e Pastagem, Instituto de Zootecnia, Universidade Federal Rural do Rio de Janeiro (UFRRJ), 23835-000 Seropédica, RJ. Email: tokarnia@ufrrj.br

${ }^{3}$ Convênio Projeto Sanidade Animal, Embrapa-UFRRJ (Ex-IBA, Instituto de Biologia Animal do Ex-IPEACS, Instituto de Pesquisa e Experimentação
}

Agropecuárias do Centro-Sul, Ministério da Agricultura), Km 47, Seropédica, RJ 23890-000. Bolsista do CNPq. E-mail:jurgen@ufrrj.br

${ }^{4}$ Pesquisador visitante do CNPq, Depto Patologia Animal, Faculdade de Veterinária, Universidade Federal de Pelotas (UFPel), Pelotas, RS 96010900. E-mail: severo@ufpel.tche.br

${ }^{5}$ Centro de Saúde e Tecnologia Rural, Universidade Federal de Campina Grande, Campus de Patos, Paraíba, PB 58700-000. E-mail: riet@cstr.ufcg.edu.br 
RESUMO.- Em função das dúvidas que ainda perduram 25 anos após a ocorrência do surto de peste suína africana (PSA), em Paracambi, Estado do Rio de Janeiro, Brasil, em 1978, são apresentados os resultados, relativos a este foco, obtidos pelos estudos epidemiológico, clínico-patológico, virológico, bacteriológico e ultra-estrutural dos casos naturais, bem como os relativos à reprodução experimental da doença no Brasil e sua confirmação por isolamento e determinação de patogenicidade realizada no Plum Island Animal Disease Center, New York, EUA. Os animais se infectaram pela ingestão de restos de comida de aviões procedentes de Portugal e da Espanha, países nos quais a doença existia. De acordo com publicação do Ministério da Agricultura, após o diagnóstico do surto de PSA descrito neste trabalho, 223 novos focos foram relatados, entre 1978 e 1979, em todas Regiões do país (Norte, Nordeste, Centro-Oeste, Sudeste e Sul) e focos adicionais em 1981, sem informações exatas referentes ao seu número. 0 último caso foi relatado em 15 de novembro de 1981, e em 5 de dezembro 1984 o Brasil foi declarado livre da PSA. Para o diagnóstico da PSA foram processadas 54.002 amostras no Departamento de Virologia do Instituto de Microbiologia da Universidade Federal do Rio de Janeiro, no período de 1978 a 1981. No processamento das amostras foram usadas as técnicas de hemadsorção em cultura de leucócitos (HAd), imunoflorescência em cortes de tecido (FATS), imunoflorescência em cultivo celular (FATCC), imuno-eletrosmoforese (IEOP) e imunoflorescência indireta (IIF). Somente 4 amostras foram positivas pela técnica de FATCC, a única das provas que inclui o isolamento viral; não é mencionada a procedência dessas amostras, mas provavelmente trata-se das amostras oriundas de Paracambi. Com base na análise de todos os dados publicados sobre o tema, na possível ocorrência de falso-positivos, na falta de informações sobre isolamento e caracterização do virus, bem como na ausência de dados sobre epidemiologia, sinais clínicos e patologia nesses outros supostos focos, pode-se concluir que o surto de Paracambi constitui a única ocorrência de PSA no Brasil, comprovada por isolamento, identificação do vírus e determinação de sua patogenicidade, e que a doença manteve-se confinada a esse local, provavelmente em função do diagnóstico precoce e da rápida adoção de eficientes medidas de controle pelas autoridades sanitárias; $o$ abate dos suínos desse rebanho iniciou-se 10 dias depois da primeira morte e 3 dias após o diagnóstico presuntivo.

TERMOS DE INDEXAÇÃO: Peste suína africana, Brasil, patologia, reprodução experimental.

\section{INTRODUÇÃO}

Mais de duas décadas após o surto de peste suína africana (PSA) que ocorreu, em 1978, no Município de Paracambi, Estado do Rio de Janeiro, e a conseqüente turbulência dele decorrente, continuam a existir dúvidas sobre o que realmente aconteceu durante e após a introdução da doença no Brasil.

Passados 25 anos, achamos conveniente apresentar cronologicamente, de forma simples e objetiva, os dados que nos permitiram estabelecer o diagnóstico de peste suína africana naquele surto. Aos exames realizados naquela época, acrescentamos o estudo ultra-estrutural de materiais guardados em blocos de pa- rafina. Adicionalmente, avaliamos os dados de trabalhos desenvolvidos por outros autores sobre a ocorrência da PSA no Brasil.

\section{MATERIAL E MÉTODOS}

Os trabalhos iniciais consistiram no levantamento epidemiológico e na determinação do quadro clínico-patológico da doença, que ocorreu em Paracambi, Estado do Rio de Janeiro, complementados por estudos bacteriológicos e virológicos. A seguir foram desenvolvidos trabalhos para a reprodução da doença, mediante inoculação de suspensão esplênica oriunda dos 4 primeiros suínos necropsiados, em 4 outros porcos vacinados contra a peste suína clássica (prova de imunidade cruzada), também com determinação do quadro clínico-patológico dos animais inoculados. Estes estudos foram complementados por exames realizados no Plum Island Animal Disease Center, New York, EUA, onde a PSA foi novamente reproduzida, o vírus foi isolado e teve sua patogenicidade determinada (Mebus \& Dardiri 1979, Mebus et al. 1979). Nos últimos 3 anos revisamos todo o nosso material histológico relativo à PSA. Em 2001, fragmentos de pulmão, baço, linfonodo, fígado e rim de cinco suínos ( $\mathrm{n}^{\mathrm{os}} 7,9,10,11$ e 12 ), incluídos em parafina, foram enviados para o Onderstepoort Veterinary Research Institute, Pretoria, África do Sul, um dos centros de referência para esta enfermidade no mundo. Adicionalmente foram feitos exames de ultramicroscopia de transmissão em material incluído em parafina, proveniente de animal naturalmente infectado naquele surto.

\section{RESULTADOS}

\section{Histórico e cronologia dos estudos iniciais}

Em 10 de maio de 1978, um de nós (CHT), patologista da Seção de Anatomia Patológica do antigo Instituto de Biologia Animal (IBA) do Ministério da Agricultura, sediado no Km 47 da antiga rodovia Rio-São Paulo, foi solicitado para que fizesse a necropsia de um suíno (7/78), procedente do Sítio Floresta, Município de Paracambi, RJ, de propriedade do Sr. Severino Pereira Filho. De um total de 1.000 porcos existentes no estabelecimento, 150 morreram em apenas uma semana. Segundo o histórico, os animais recebiam ração comercial e algo chamado de "mangonga" (de início, não nos foi mencionado que tipo de alimento seria esse). $O$ proprietário achava que a causa das mortes era a ração comercial e o veterinário da firma produtora da ração dizia que se tratava de peste suína clássica (PSC); o primeiro contra-argumentava que seus animais seriam regularmente vacinados contra essa doença.

\section{A suspeita}

A necropsia do suíno (7/78) acima mencionado revelou hemorragias, de diversas formas, em vários órgãos, linfonodos e serosas, que impressionavam pela extensão, gravidade e freqüência, além das marcadas lesões pulmonares (pleurite fibrinosa e hepatização do parênquima pulmonar).

Em função das alterações encontradas, da grande mortandade em curto espaço de tempo, além da informação de que os animais teriam sido vacinados contra peste suína clássica, suspeitamos que pudesse tratar-se de peste suína africana (PSA). É importante ressaltar que no Estado do Rio de Janeiro, àquela época, a PSC cursava com hemorragias muito leves, como costuma acontecer em regiões em que os suínos vão adquirindo resistência ao vírus.

No mesmo dia (10.5.78), o veterinário da firma fabricante da ração comercial, Dr. Francisco de Assis Moreira Lima, veio ao 
Instituto para saber o resultado da necropsia. Informamos que se tratava de peste suína (não especificamos qual das pestes suínas) e solicitamos mais animais para exame necroscópico. Juntamente com esse colega, no mesmo dia fomos ao Sítio Floresta, Paracambi, para examinar a situação in loco.

\section{A origem da fonte de infecção}

No Sítio Floresta, de início, constatamos que a "mangonga" era constituída por restos de comida oriundos do Restaurante Mariott, empresa que abastecia aviões de diversas linhas aéreas (entre essas, TAP e IBERIA, que mantinham linhas regulares para Portugal e Espanha, países, à época, endêmicos para PSA) com gêneros alimentícios e que recolhia os restos de comida destes aviões. O proprietário do Sítio apanhava no Aeroporto Internacional do Rio de Janeiro, distante 70 km, estes restos de comida em caminhão próprio, diversas vezes por semana. Esses resíduos de alimentos não eram cozidos antes de serem dados aos suínos.

\section{Prosseguimento do estudo}

Verificamos que grande número de animais estava enfermo, exibindo sinais clínicos variados como hemorragias cutâneas, tosse, hipertermia, diarréia e apatia. Constantemente morriam suínos, que eram enterrados na propriedade. Essas informações e o quadro clínico fortaleceram sobremaneira a suspeita inicial de tratar-se da PSA.

Trouxemos dois outros suínos (8/78 e 10/78) agonizantes para o IBA, um dos quais (8/78) amanheceu morto no dia seguinte (11.5.78). À necropsia constatamos o mesmo quadro hemorrágico de extrema gravidade, acrescido de acentuada esplenomegalia e pericardite fibrinosa, lesões que novamente indicavam tratar-se de PSA.

A essa altura, por segurança, solicitamos a opinião do Professor Wilhelm O. Neitz, renomado veterinário sul-africano, com ampla experiência em PSA, autor do capítulo sobre essa doença no livro da FAO, intitulado Emerging Diseases of Animals; esse professor lecionava no Curso de Pós-Graduação da Universidade Federal Rural do Rio de Janeiro. A sua opinião, ao examinar o cadáver do Suíno 8/78, foi de que, sem dúvida, tratava-se de PSA. Convidado, aceitou acompanhar-nos em mais uma visita ao Sítio Floresta. Ao deparar-se com a situação, o Prof. Neitz fez apelos veementes para que imediatamente comunicássemos o fato às autoridades responsáveis pela sanidade na área de veterinária, ainda mais que surpreendemos empregados do sítio abatendo suínos para que a carne fosse comercializada. $O$ criador foi advertido da extrema gravidade da situação.

A necropsia do terceiro suíno (9/78), realizada em 11.5.78, no Sítio, na presença do Prof. Neitz, evidenciou o mesmo tipo de hemorragias já descrito, com destaque para a marcada esplenomegalia e pericardite.

\section{Notificação às autoridades}

Em 12.5.78 foi notificada a Defesa Sanitária Animal do Ministério da Agricultura, em Brasília, através de ligação telefônica. $\mathrm{O}$ fato também foi comunicado à Embrapa- Empresa Brasileira de Pesquisa Agropecuária. Nesse mesmo dia, à tarde, morreu e foi necropsiado o quarto suíno (10/78), verificando-se quadro macroscópico semelhante ao anteriormente mencionado.
Desenvolvimento das medidas para extinção do foco e profilaxia de sua expansão

Ainda em 12.5.78, à noite, compareceu ao Instituto de Biologia Animal (IBA) o Dr. Rômulo de Paula Costa, Substituto do Diretor do DEMA/RJ (Delegacia do Ministério da Agricultura/RJ), solicitando maiores detalhes sobre o surto. Também nesse mesmo dia chegou ao Instituto o Dr. Sergio Coube Bogado, vindo de Belo Horizonte, por solicitação do Dr. Ubiratan M. Serrão (Chefe da Subsecretaria de Defesa Sanitária Animal, Min. Agricultura, Brasília); o Dr. Sergio Bogado havia estudado surtos de PSA in loco na Península Ibérica. Esse colega manifestou-se plenamente de acordo com o diagnóstico e, já que para tal também fora incumbido, levou material (tecidos) dos suínos coletado neste surto, para o Dr. Ronaldo Reis (Prof. da disciplina de Doenças Infecciosas da Escola de Veterinária da Universidade Federal de Minas Gerais em Belo Horizonte), que, segundo ele, disporia das técnicas laboratoriais necessárias para confirmar o diagnóstico. Entregamos ao Dr. Bogado amostras do material biológico dos quatro suínos necropsiados até aquele dia, bem como de dois outros suínos (11/78 e 12/78) por nós necropsiados no dia seguinte, durante nova visita ao Sítio Floresta (presentes o Dr. Sergio Bogado e o Dr. Carlos R. Lima, Chefe do GEPA/RJ - Grupo Executivo da Produção Animal no Estado do Rio de Janeiro, que compareceu ao Instituto em 13.5.78).

Enquanto no sábado, dia 13.5.78, o Dr. Rômulo de Paula Costa se concentrava nos esforços para conseguir, junto às autoridades militares, um destacamento que garantisse o estabelecimento de quarentena no Sítio Floresta, o Dr. Carlos Lima tomava providências para extinção do foco.

No mesmo dia, as autoridades sanitárias conseguiram, com ajuda da Polícia Militar, estabelecer a quarentena no referido Sítio e teve início a extinção do foco. O sacrifício e cremação dos suínos restantes do Sítio Floresta, Paracambi, foram realizados nas dependências do IBA.

\section{Caracterização do quadro patológico, diagnósticos diferenciais e reprodução experimental da PSA}

Resumo dos achados de necropsia dos suínos mortos naturalmente. À necropsia dos 6 suínos, predominava um quadro hemorrágico, mais marcado nos linfonodos, que ao corte apresentavam-se com periferia avermelhada, ou mosqueados de vermelho ou ainda eram totalmente vermelho-escuros e aumentados de volume, parecendo hematomas. Estavam afetados, sobretudo, os linfonodos retrofaríngeos, os do hilo do fígado, os gástricos e os lombo-aórticos. Havia hemorragias no coração, na superfície dos rins, na mucosa da vesícula biliar, no tecido subcutâneo e nos músculos, bem como alterações congestivohemorrágicas na mucosa do tubo digestivo. Entre as alterações importantes observaram-se ainda derrames serosos, serofibrinosos ou fibrinosos na cavidade torácica, no saco pericárdico e na cavidade abdominal, edema e hepatização pulmonares. Verificou-se também esplenomegalia na maioria dos casos. O sangue era aquoso.

Resumo dos achados histopatológicos dos suínos mortos naturalmente (Fig. 1,2,3,5). De uma forma geral, pulmões, linfonodos, baço, estômago e intestinos foram os órgãos mais severamente afetados nos animais que sofreram in- 


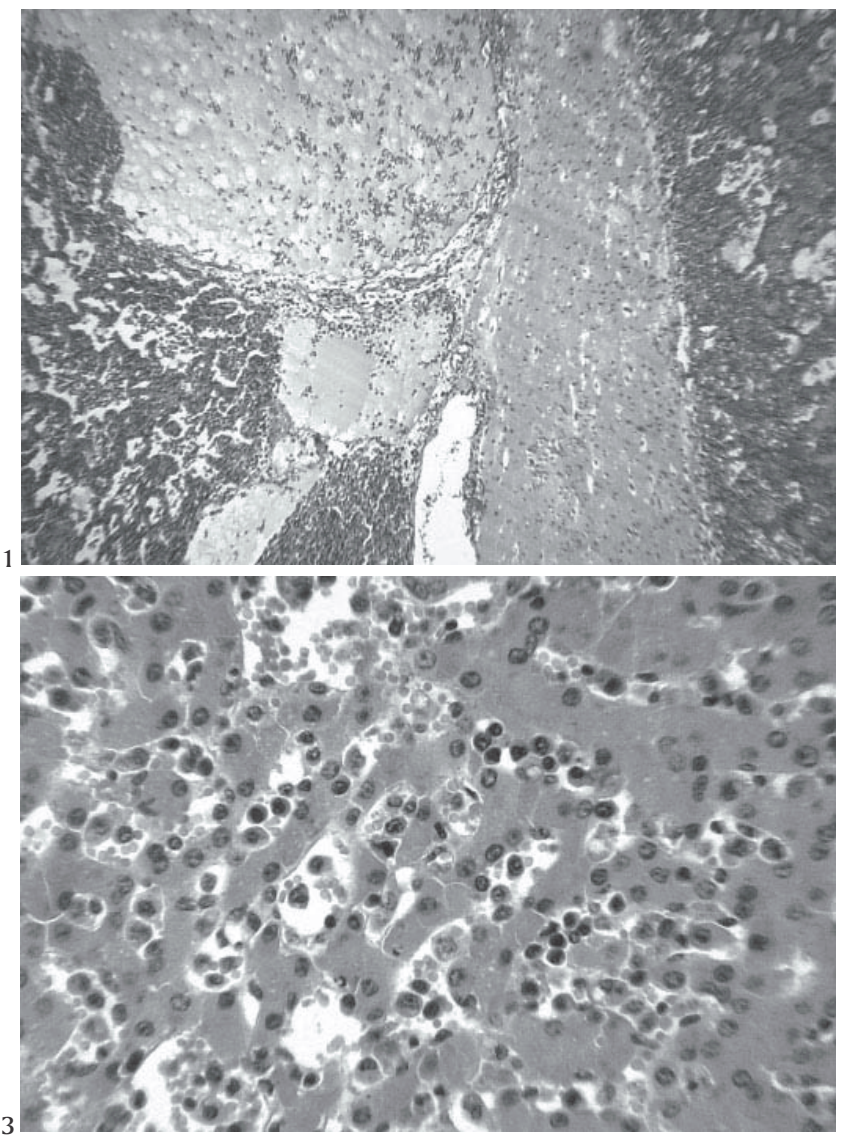

Fig. 1. Espessamento de septos interlobulares pulmonares por fluido rico em proteína e dilatação de linfáticos. Caso natural de peste suína africana (PSA) do surto em Paracambi, RJ (Suíno 10, registro SAP 22457). HE, obj.10.

Fig.3. Moderada leucocitostase e alterações regressivas das células circulantes, na área centrolobular e nos sinusóides hepáticos. Caso natural de PSA do surto em Paracambi, RJ (Suíno 9, registro SAP 22456). HE, obj.25.

fecção natural pelo vírus da PSA. Nos pulmões verificou-se pneumonia intersticial difusa ou localmente extensiva, como lesão mais proeminente; havia moderado espessamento da parede alveolar determinado por infiltração de células inflamatórias mono e polimorfonucleares e por tumefação e microvacuolização de células epiteliais, por vezes, com pequena quantidade dessas mesmas células, fibrina e hemácias na luz de parte dos alvéolos. Os septos interlobulares e a pleura, bem como vasos linfáticos apresentavam-se variavelmente dilatados e preenchidos por derrame sero-fibrinoso e/ou por sangue ou ainda por exsudato misto (polimorfonucleares e células mononucleares). Em alguns casos havia fibrose incipiente representando tentativa de organização dos exsudatos intersticial e subpleural. Pleurite sero-fibrinosa ou sero-supurativa foi vista em alguns animais, sempre associada à broncopneumonia catarro-purulenta ou supurativa secundárias. Na submucosa de brônquios e de bronquíolos maiores, eventualmente havia leve a moderada infiltração inflamatória mista. Em parte dos suínos, o

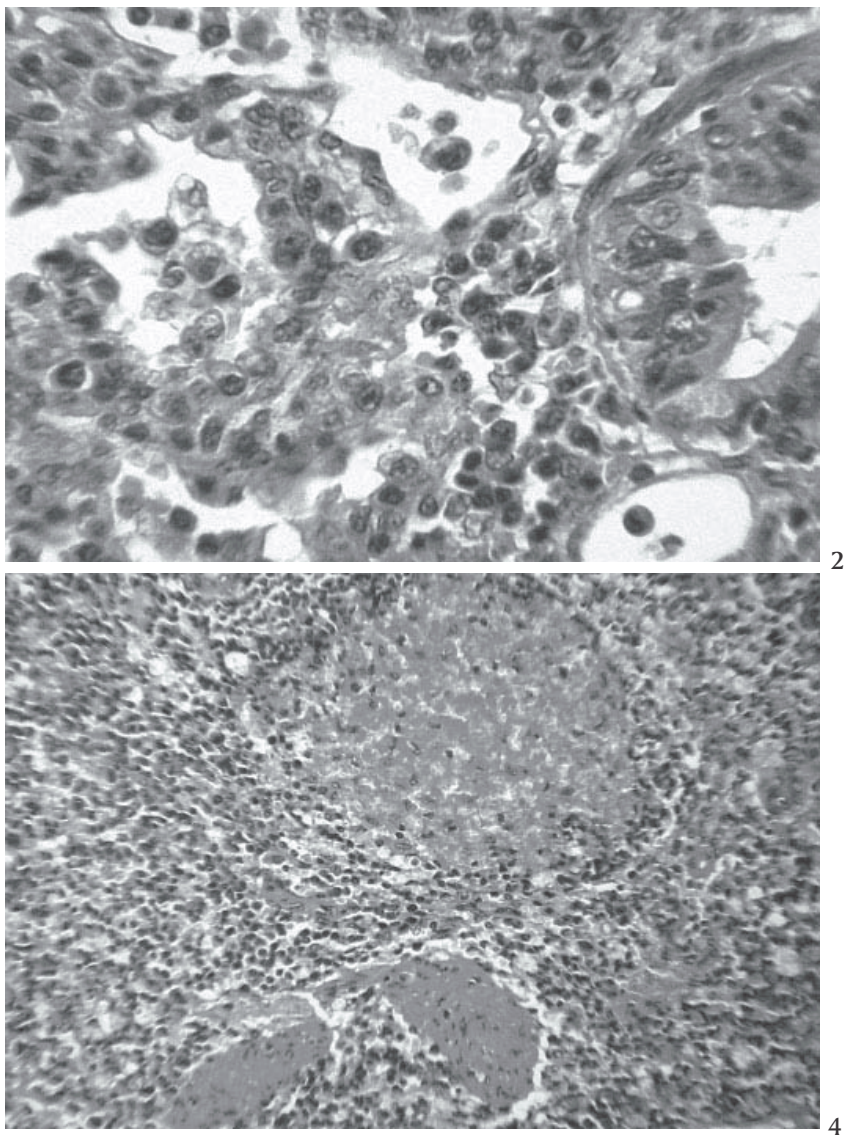

Fig.2. Área de pneumonia intersticial mista adjacente a pequeno bronquíolo. Caso natural de PSA do surto em Paracambi, RJ (Suíno 12, registro SAP 22459). HE, obj.40.

Fig.4. Necrose de trabécula (bainha de Schweigger-Seidel) esplênica. Caso experimental de PSA do surto em Paracambi, RJ (Suíno 7A, registro SAP 22464). HE, obj.10.

endotélio dos vasos sangüíneos do pulmão, sobretudo das arteríolas e vênulas, evidenciou acentuada vacuolização/ tumefação citoplasmática, associada a hipercromatismo e aumento de volume nuclear ou à proliferação endotelial. Por vezes, algumas arteríolas mostravam-se espessadas, com desorganização da camada muscular e aspecto fibrinóide. Leucocitostase (grande quantidade de leucócitos dentro de vaso) e alterações regressivas em leucócitos intravasculares foram encontradas em dois animais. No fígado de praticamente todos os animais observou-se leucocitostase dentro de artérias, veias e capilares sinusóides; parte desses leucócitos evidenciava alterações regressivas (picnose, cariorrexia, vacuolização citoplasmática). Necrose individual ou de pequenos grupos de hepatócitos, bem como leve vacuolização fizeram-se presentes em poucos casos. Nos espaços-porta havia infiltração por leucócitos, parte dos quais também necrosada, associada a leve fibrose, lesões também observadas em algumas porções da cápsula hepática. Alterações vasculares como 

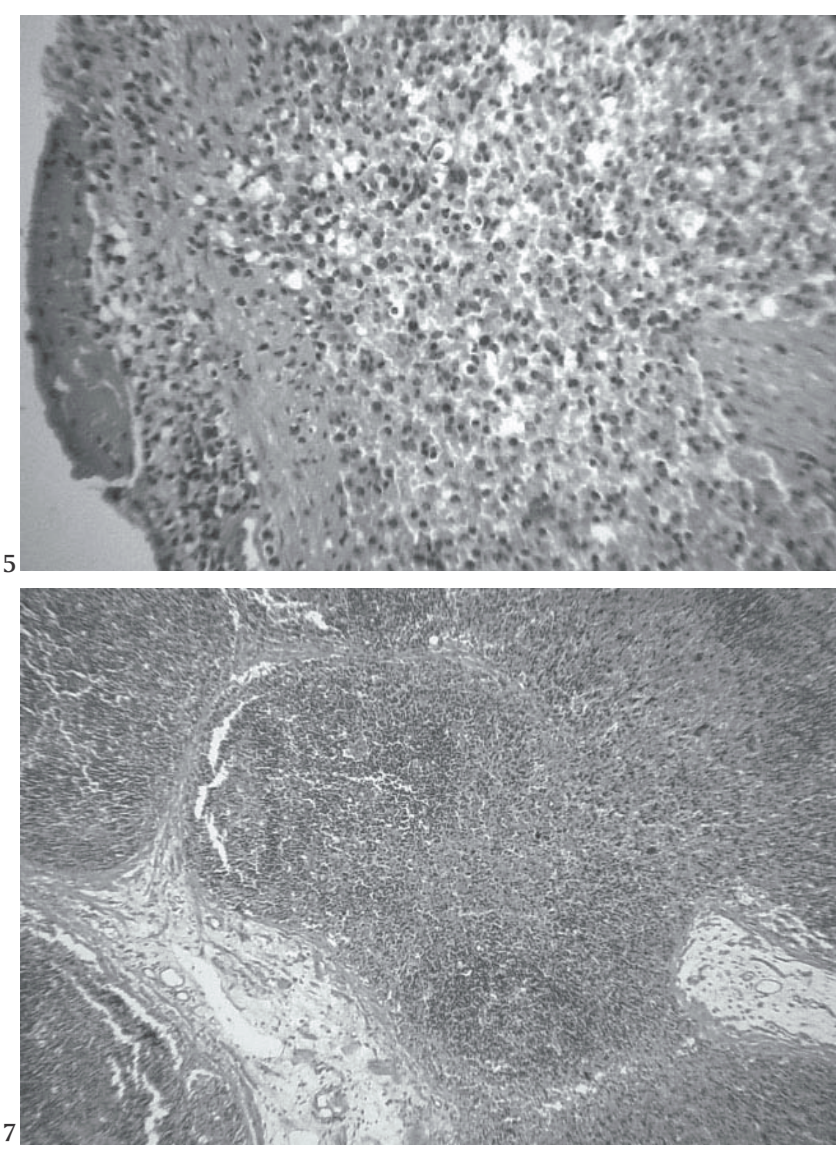

Fig.5. Capsulite e pericapsulite esplênicas. Caso natural de PSA do surto em Paracambi, RJ (Suíno 12, registro SAP 22459). HE, obj.16.

Fig. 7. Grande quantidade de sangue drenado em linfonodo. Caso experimental de PSA, Km 47 (Suíno 7A, registro SAP 22464). HE, obj. 4.

as descritas nos vasos do pulmão e corpúsculos de choque eram pouco conspícuas. No baço havia congestão, em vários graus, muitas vezes acompanhada de derrame sero-fibrinoso e/ou infiltração leucocitária na cápsula, esta última presente também nas trabéculas esplênicas. As alterações regressivas eram representadas por depleção linfóide e, mais raramente, necrose nos folículos e nas trabéculas (bainhas de SchweiggerSeidel), bem como por pequenas áreas de necrose coagulativa. Proliferação de células reticulares e marcada infiltração por polimorfonucleares foram ocasionalmente vistas na polpa vermelha; havia numerosos megacariócitos ou megacarioblastos em três animais; lesões vasculares pouco proeminentes foram verificadas em um suíno. Os seios subcapsulares dos linfonodos revelavam grande quantidade de hemácias, muitas vezes associadas a numerosos leucócitos, em parte necróticos, com alguma fibrina ou leve fibrose (parcialmente organizada). Derrame sero-fibrinoso e material protéico coagulado com aspecto semelhante a trombos em vasos linfáticos pericapsulares, bem como infiltrados mono e polimorfonucleares na cápsula e nos
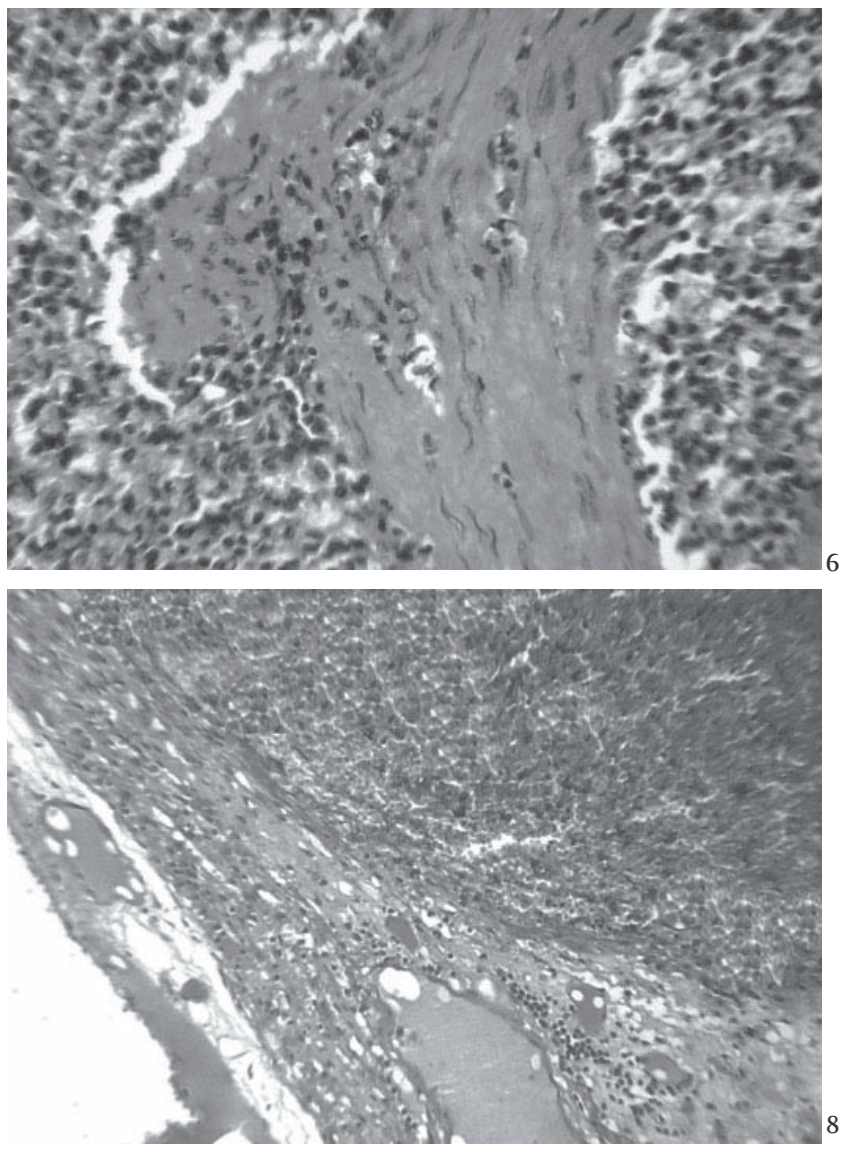

Fig.6. Infiltração inflamatória em trabécula esplênica. Caso experimental de PSA do surto em Paracambi, RJ (Suíno 7A, registro SAP 22464).HE, obj.16.

Fig.8. Acúmulo de sangue em seios subcapsulares de linfonodo. Caso experimental de PSA, Km 47 (Suíno 7A, registro SAP 22464). HE, obj.10.

septos foram observados em alguns casos. Depleção linfóide ou necrose coagulativa de folículos foram vistas em parte dos suínos; grandes áreas de necrose foram observadas em apenas um animal. Infiltração difusa de eosinófilos, relativamente marcada, presença de megacarió-citos/megacarioblastos e proliferação de células reticulares se fizeram presentes com baixa frequiência; lesões vasculares e congestão foram verificadas cada uma em um animal. $\mathrm{O}$ estômago de um animal apresentou submucosa muito espessada por exsudato fibrinoso entremeado com focos supurativos e detritos celulares leucocitários, também contidos em vasos linfáticos; essas lesões se estendiam, com menor intensidade, à camada muscular. Adicionalmente verificaram-se trombos venosos, associados à vasculite e à perivasculite. Nos três animais que tiveram o órgão coletado, havia áreas de necrose coagulativa com ou sem hemorragias na mucosa. No sistema nervoso central não havia lesões significativas.

Em 16.5.78, atendendo solicitação, o Prof. Jefferson Andrade dos Santos, Professor Titular da Universidade Federal Fluminense, 
com ampla experiência em PSA, vivenciada em Moçambique, examinou os cortes histológicos e também concluiu que se tratava de PSA.

\section{Estudos bacteriológicos e virológicos}

Os exames bacteriológicos, realizados pela Dra. Charlotte $\mathrm{H}$. Langenegger, da Seção de Microbiologia do IBA, nos tecidos dos quatro primeiros suínos necropsiados, resultaram negativos. $\mathrm{O}$ Prof. Ronaldo Reis, da UFMG, Belo Horizonte, apenas realizou tentativas para o isolamento dos agentes da ruiva e da PSC; ambas resultaram negativas. Não foram feitos outros exames pelo mesmo.

\section{Reprodução da doença e prova de imunidade cruzada} com peste suína clássica (PSC)

Uma vez que a Seção de Virologia do IBA estava desativada e também porque não havia outra instituição no Rio de Janeiro que dispusesse, naquele momento, de técnicas laboratoriais específicas (provas de hemadsorção e imunoflorescência) para confirmação do diagnóstico de PSA, optamos pelo teste de imunidade cruzada para, pelo menos de início, podermos descartar a possibilidade de que se tratasse de uma cepa muito patogênica do vírus da PSC. Dessa forma, ainda em 12.5.78, do baço de cada um dos quatro suínos necropsiados foi preparada uma suspensão (na Seção de Microbiologia do IBA) que foi inoculada, por via intramuscular, em quatro suínos jovens (com alguns meses de idade) adquiridos de proprietário fidedigno, que confirmadamente vacinava contra PSC. Esses suínos inoculados permaneceram em recinto rigorosamente isolado no Biotério do IBA. O trabalho de inoculação foi realizado sob orientação técnica do Prof. W.O.Neitz.

Entre 4 e 6 dias após a inoculação, os quatro suínos adoeceram, evidenciando febre e progressiva diminuição do apetite até anorexia. Dois suínos (7A e 8A) morreram, um no $10^{\circ}$, o outro no $11^{\circ}$ dias após a inoculação (em 22 e 23.5.78); os outros dois suínos inoculados (9A e 10A), já enfermos, foram sacrificados por determinação das autoridades sanitárias, em 27 de maio de 1978. No Anexo (Fig. 9 a 13) constam as curvas térmicas dos quatro suínos inoculados e de um animal-controle, que não adoeceu.
Resumo dos achados de necropsia nos suínos inoculados Também nos suínos inoculados, as principais alterações eram de natureza congestivo-hemorrágica, afetando sobretudo os linfonodos internos que, às vezes, pareciam hematomas, o coração (peri, epi e endocárdio), a pleura, a mucosa da vesícula biliar, da bexiga e do intestino e a superfície dos rins. Entre as alterações importantes havia ainda edema pulmonar e leve esplenomegalia.

Resumo dos achados histopatológicos nos suínos inoculados (Fig. 4,6,7,8)

Nos suínos inoculados, da mesma forma, os órgãos mais severamente afetados foram os pulmões, linfonodos, baço e tubo digestivo. No pulmão verificou-se pneumonia intersticial; nos septos interlobulares e na pleura havia derrame sero-fibrinoso com infiltrados inflamatórios. Verificaram-se lesões vasculares sob forma de necrose e degeneração das células endoteliais e proliferação endotelial com leucócitos degenerados ou necróticos dentro de vasos. No figado foram vistas alterações regressivas em leucócitos intravasculares. No baço verificou-se proliferação endotelial de vasos arteriais. Nos linfonodos havia acentuada drenagem de sangue nos seios subcapsulares e da medula, com presença de fibrina e leucócitos em diferentes fases de degeneração até necrose. No tubo digestivo observaram-se congestão, hemorragias e necrose.

Os principais achados de necropsia e as alterações histológicas verificados nos casos naturais e experimentais relatados aqui estão esquematizados nos Quadros 1 a 7.

\section{Exames realizados no Plum Island Animal Disease Center, New York, EUA}

Em 24.5.78 foi entregue aos Drs Ubiratan M. Serrão e Cezar Eduardo Rozas, devidamente acondicionado, material oriundo dos dois primeiros suínos necropsiados (7/78 e 8/78), dos dois suínos que morreram espontaneamente pela infecção experimental (7A/78 e 8A/78), bem como de outros quatro suínos, suspeitos de estarem na fase inicial da doença e sacrificados para esse fim no Sítio Floresta (Suínos 13/78, 15/78, 16/78, 17/78 e 18/78), a fim de que fosse enviado aos EUA, por intermédio do Centro Panamericano de Febre Aftosa, para a confirmação definitiva do diagnóstico. Dos quatro primeiros suínos menciona-

Quadro 1. Principais alterações macroscópicas observadas no pulmão e no coração dos suínos com PSA (natural e experimental) no surto de Paracambi, Rio de Janeiro

\begin{tabular}{|c|c|c|c|c|c|c|c|c|c|}
\hline \multirow{3}{*}{$\begin{array}{l}\text { Suíno } \\
\text { no. }\end{array}$} & \multicolumn{5}{|c|}{ Pulmão } & \multicolumn{4}{|c|}{ Coração } \\
\hline & \multirow{2}{*}{$\begin{array}{c}\text { Pleurite } \\
\text { fibrinosa }\end{array}$} & \multirow{2}{*}{$\begin{array}{c}\text { Pleura com } \\
\text { líquido } \\
\text { cítrico }\end{array}$} & \multirow{2}{*}{$\begin{array}{l}\text { Edema } \\
\text { alveolar }\end{array}$} & \multirow{2}{*}{$\begin{array}{c}\text { Edema } \\
\text { interlobular } \\
\text { (septos) }\end{array}$} & \multirow[t]{2}{*}{ Hepatização } & \multirow{2}{*}{$\begin{array}{l}\text { Hidrope- } \\
\text { ricárdio }\end{array}$} & \multirow{2}{*}{$\begin{array}{c}\text { Pericardite } \\
\text { fibrinosa }\end{array}$} & \multicolumn{2}{|c|}{ Hemorragias } \\
\hline & & & & & & & & Epicárdio & Endocárdio \\
\hline 07 & $+{ }^{a}$ & - & - & + & + & + & - & +++ & + \\
\hline 08 & - & - & +++ & + & - & - & + & - & - \\
\hline 09 & - & - & +++ & - & - & - & ++ & - & - \\
\hline 10 & - & + & +++ & - & + & + & - & ++ & - \\
\hline 11 & + & ++ & ++ & - & + & ++ & - & - & - \\
\hline 12 & - & - & ++ & - & - & - & - & - & - \\
\hline 07A & - & - & + & - & - & - & - & ++ & ++ \\
\hline 08A & - & - & ++ & ++ & - & - & - & - & - \\
\hline $09 \mathrm{~A}$ & - & - & - & - & - & - & - & + & - \\
\hline $10 \mathrm{~A}$ & - & - & - & - & - & - & - & - & - \\
\hline
\end{tabular}


Quadro 2. Principais alterações macroscópicas observadas em órgãos linfóides e aparelho urinário dos suínos com PSA (natural e experimental) no surto de Paracambi, Rio de Janeiro

\begin{tabular}{|c|c|c|c|c|c|c|}
\hline \multirow{2}{*}{$\begin{array}{c}\text { Suíno } \\
\text { no. }\end{array}$} & \multicolumn{2}{|r|}{ Baço } & \multicolumn{2}{|c|}{ Linfonodos } & \multicolumn{2}{|l|}{ Rins } \\
\hline & $\begin{array}{c}\text { Aumento } \\
\text { volume }\end{array}$ & $\begin{array}{c}\text { Hemorragias } \\
\text { subcapsulares }\end{array}$ & $\begin{array}{l}\text { Aspecto } \\
\text { marmóreo }\end{array}$ & Vermelhos & $\begin{array}{l}\text { Hemorragias } \\
\text { subcapsulares }\end{array}$ & $\begin{array}{r}\text { Pélvis com } \\
\text { hemorragias }\end{array}$ \\
\hline 07 & - & + & - & + & +++ & ++ \\
\hline 08 & +++ & +++ & + & + & +++ & - \\
\hline 09 & +++ & - & + & - & $(+)$ & - \\
\hline 10 & ++ & +++ & +++ & +++ & + & - \\
\hline 11 & + & ++ & +++ & - & + & - \\
\hline 12 & + & - & - & - & ++ & - \\
\hline 07A & - & - & - & +++ & ++ & ++ \\
\hline 08A & + & - & - & +++ & + & - \\
\hline $09 \mathrm{~A}$ & ++ & - & - & - & - & - \\
\hline $10 \mathrm{~A}$ & + & - & + & - & ++ & - \\
\hline
\end{tabular}

Quadro 3. Outros achados macroscópicos em suínos com PSA (natural e experimental) no surto de Paracambi, Rio de Janeiro

\begin{tabular}{cccccccc}
\hline $\begin{array}{c}\text { Suíno } \\
\text { no. }\end{array}$ & Anemia & $\begin{array}{c}\text { Edema sub- } \\
\text { cutâneo }\end{array}$ & $\begin{array}{c}\text { Hemorragias } \\
\text { musculares }\end{array}$ & $\begin{array}{c}\text { Congestão das } \\
\text { meninges }\end{array}$ & $\begin{array}{c}\text { Ascite } \\
\text { memorragias nas }\end{array}$ & $\begin{array}{c}\text { Avermelhamento/hemor- } \\
\text { serosas viscerais } \\
\text { dos órgãos }\end{array}$ & $\begin{array}{c}\text { Edema da } \\
\text { Estômago da mucosa }\end{array}$ \\
parede da & abdominais & Intestino vesícula biliar \\
grosso
\end{tabular}

\begin{tabular}{|c|c|c|c|c|c|c|c|c|c|}
\hline 09 & +++ & - & - & - & - & +++ & +++ & - & - \\
\hline 11 & - & - & - & - & ++ & + & - & - & - \\
\hline 12 & - & - & - & - & - & - & +++ & +++ & - \\
\hline 07A & ++ & - & + & - & - & +++ & + & + & - \\
\hline $10 \mathrm{~A}$ & - & - & - & +++ & - & - & - & - & - \\
\hline
\end{tabular}

Quadro 4. Principais alterações histológicas nos pulmões e na pleura dos suínos com PSA (natural e experimental) no surto de Paracambi, Rio de Janeiro

\begin{tabular}{|c|c|c|c|c|c|c|c|c|c|c|c|c|c|c|}
\hline \multirow{2}{*}{$\begin{array}{l}\text { Suíno no. } \\
\text { (reg. SAP) }\end{array}$} & \multirow{2}{*}{$\begin{array}{l}\text { Pneumonia } \\
\text { intersticial }\end{array}$} & \multirow{2}{*}{$\begin{array}{l}\text { Bronco- } \\
\text { pneumo- } \\
\text { nia se- } \\
\text { cundária }\end{array}$} & \multirow{2}{*}{$\begin{array}{c}\text { Conges- } \\
\text { tão } \\
\text { difusa }\end{array}$} & \multicolumn{2}{|c|}{ Alvéolos } & \multicolumn{4}{|c|}{ Septos } & \multirow{2}{*}{$\begin{array}{l}\text { Nos brôn- } \\
\text { quios infil- } \\
\text { trados mis- } \\
\text { tos, sub- } \\
\text { epiteliais }\end{array}$} & \multirow{2}{*}{$\begin{array}{c}\text { Lesões } \\
\text { vascu- } \\
\text { lares }\end{array}$} & \multicolumn{3}{|c|}{ Pleurite } \\
\hline & & & & $\begin{array}{l}\text { Hemor- } \\
\text { ragias }\end{array}$ & $\begin{array}{l}\text { Edema e } \\
\text { fibrina }\end{array}$ & $\begin{array}{c}\text { Hemor- } \\
\text { ragias }\end{array}$ & $\begin{array}{l}\text { Derrame } \\
\text { seroso } \\
\text { e/ou fi- } \\
\text { brinoso }\end{array}$ & $\begin{array}{l}\text { Linfáti- } \\
\text { cos dre- } \\
\text { nando } \\
\text { sangue }\end{array}$ & $\begin{array}{c}\text { Fibrose } \\
\text { incipi- } \\
\text { ente }\end{array}$ & & & $\begin{array}{l}\text { Sero-fi- } \\
\text { brinosa }\end{array}$ & $\begin{array}{l}\text { Necro- } \\
\text { tizante }\end{array}$ & Crônica \\
\hline 07 (22454) & ++ & ++ & ++ & ++ & - & ++ & - & ++ & - & - & - & ++ & - & - \\
\hline 08 (22455) & $+(+)$ & - & - & - & ++ & - & ++ & - & - & - & - & - & - & - \\
\hline 09 (22456) & $++(+)$ & - & - & - & - & - & - & - & - & + & - & - & - & + \\
\hline $11(22458)$ & + & + (áreas) & - & - & - & - & - & - & - & + & + & - & + & - \\
\hline 12 (22459) & $++(+)$ & - & - & - & - & - & - & - & - & + & - & - & - & + \\
\hline 07A (22464) & $+(+)$ & $(+)$ & - & + & + & - & - & - & + & - & - & - & - & + \\
\hline 08A (22463) & $+(+)$ & $(+)$ & - & ++ & + & + & ++ & + & + & - & ++ & ++ & - & - \\
\hline 09A (22466) & ++ & - & - & - & - & - & - & - & + & - & + & - & - & - \\
\hline $10 \mathrm{~A}(22467)$ & $(+) /++$ & - & + & - & - & - & - & - & + & - & + & - & - & - \\
\hline
\end{tabular}

dos foram enviados fragmentos de baço, do Suíno 18/78 fragmentos de linfonodos e dos outros animais fragmentos de baço, fígado e linfonodos. Em 1 de junho de 1978, recebemos a comunicação verbal, através do Dr. Carlos R. Lima, que o Laboratório de Plum Island (Plum Island Animal Disease Center), havia confirmado o diagnóstico de PSA.
Mais tarde tivemos acesso a uma cópia da carta, assinada pelo Dr. A.H. Dardiri, Chefe do Laboratório de Diagnóstico daquele Centro (Anexo, Fig. 14).

Por solicitação nossa, o Dr. A.H. Dardiri nos enviou, em 5 de janeiro de 1979, carta com os detalhes dos exames realizados com os respectivos resultados (Anexo, Fig. 15). 
Quadro 5. Principais alterações histológicas no fígado dos suínos com PSA (natural e experimental) no surto de Paracambi, Rio de Janeiro

\begin{tabular}{|c|c|c|c|c|c|c|c|c|c|c|c|}
\hline $\begin{array}{l}\text { Suíno } \\
\text { no. }\end{array}$ & $\begin{array}{l}\text { Leucoci- } \\
\text { tostase }\end{array}$ & $\begin{array}{l}\text { Necrose } \\
\text { hepática }\end{array}$ & $\begin{array}{l}\text { Necrose de } \\
\text { leucócitos }\end{array}$ & $\begin{array}{l}\text { Infiltrados } \\
\text { inflamatórios } \\
\text { mistos nos es- } \\
\text { paços-porta }\end{array}$ & $\begin{array}{c}\text { Proliferação } \\
\text { de células } \\
\text { de Kupffer }\end{array}$ & $\begin{array}{l}\text { Septos } \\
\text { com fi- } \\
\text { brose }\end{array}$ & $\begin{array}{c}\text { Infiltrados } \\
\text { inflamatórios } \\
\text { na cápsula }\end{array}$ & $\begin{array}{l}\text { Corpúsculos } \\
\text { de choque }\end{array}$ & $\begin{array}{c}\text { Lesões } \\
\text { vasculares }\end{array}$ & $\begin{array}{l}\text { Hematopoese } \\
\text { extramedular }\end{array}$ & $\begin{array}{c}\text { Vacuolização } \\
\text { de células } \\
\text { hepáticas }\end{array}$ \\
\hline 07 & ++ & + & - & - & - & - & - & - & - & - & - \\
\hline 08 & ++ & - & - & - & - & - & - & - & - & - & - \\
\hline 09 & $++(+)$ & $(+)$ & - & $+(+)$ & - & - & + & - & - & - & - \\
\hline 10 & + & - & - & $+(+)$ & ++ & + & - & - & - & - & - \\
\hline 11 & + & - & - & ++ & - & - & - & - & + & - & - \\
\hline 12 & + & - & - & + & + & + & - & - & - & - & - \\
\hline 07A & - & + & + & - & - & - & - & +++ & - & - & + \\
\hline 08A & + & + & + & - & - & - & - & ++ & + & - & - \\
\hline $09 \mathrm{~A}$ & - & - & - & - & ++ & - & - & - & - & ++ & - \\
\hline $10 \mathrm{~A}$ & - & - & - & - & - & + & - & - & - & - & + \\
\hline
\end{tabular}

Quadro 6. Principais alterações histológicas no baço dos suínos com PSA (natural e experimental) no surto de Paracambi, Rio de Janeiro

\begin{tabular}{|c|c|c|c|c|c|c|c|c|c|}
\hline $\begin{array}{l}\text { Suíno } \\
\text { no. }\end{array}$ & Congestão & $\begin{array}{c}\text { linfiltrados } \\
\text { inflamatórios } \\
\text { na cápsula }\end{array}$ & $\begin{array}{c}\text { Infiltrados } \\
\text { inflamatórios } \\
\text { nas trabéculas }\end{array}$ & $\begin{array}{c}\text { Necrose } \\
\text { na cápsula }\end{array}$ & $\begin{array}{l}\text { Necrose nas } \\
\text { trabéculas }\end{array}$ & $\begin{array}{c}\text { Áreas de } \\
\text { necrose } \\
\text { coagulativa }\end{array}$ & $\begin{array}{l}\text { Depleção } \\
\text { linfóide }\end{array}$ & $\begin{array}{c}\text { Presença de } \\
\text { megacariócitos }\end{array}$ & $\begin{array}{c}\text { Lesões } \\
\text { vasculares }\end{array}$ \\
\hline
\end{tabular}

\begin{tabular}{|c|c|c|c|c|c|c|c|c|c|}
\hline 07 & + & - & - & - & - & - & ++ & - & - \\
\hline 08 & $++(+)$ & - & + & - & - & - & - & - & - \\
\hline 09 & ++ & + & + & + & + & - & - & - & - \\
\hline 10 & + & $(+)$ & + & - & - & ++ & $+(+)$ & + & - \\
\hline 11 & - & + & + & - & - & ++ & ++ & ++ & + \\
\hline 12 & + & + & + & - & - & - & $++(+)$ & ++ & - \\
\hline 07A & - & - & + & - & + & + & - & - & - \\
\hline 08A & Não coletado & & & & & & & & \\
\hline 09A & + & + & + & - & - & - & - & - & + \\
\hline $10 \mathrm{~A}$ & + & + & + & - & - & - & + & - & + \\
\hline
\end{tabular}

Quadro 7. Principais alterações histológicas nos linfonodos dos suínos com PSA (natural e experimental) no surto de Paracambi, Rio de Janeiro

\begin{tabular}{|c|c|c|c|c|c|c|c|c|c|c|c|c|}
\hline \multirow{2}{*}{$\begin{array}{c}\text { Suíno } \\
\text { no. }\end{array}$} & \multirow{2}{*}{$\begin{array}{c}\text { Derrame } \\
\text { serofibri- } \\
\text { noso peri- } \\
\text { capsular }\end{array}$} & \multirow[t]{2}{*}{$\begin{array}{l}\text { Inflamação da } \\
\text { cápsula/septos }\end{array}$} & \multirow{2}{*}{$\begin{array}{c}\text { Necrose } \\
\text { coagulativa } \\
\text { de folículos } \\
\text { (cariorrexia } \\
\text { e picnose) }\end{array}$} & \multirow[t]{2}{*}{$\begin{array}{l}\text { Depleção } \\
\text { linfóide }\end{array}$} & \multicolumn{2}{|c|}{$\begin{array}{c}\text { Seios subcapsulares } \\
\text { e medula }\end{array}$} & \multirow[t]{2}{*}{$\begin{array}{l}\text { Eosino- } \\
\text { filia }\end{array}$} & \multirow{2}{*}{$\begin{array}{c}\text { Fibrose } \\
\text { nos seios } \\
\text { marginais }\end{array}$} & \multirow{2}{*}{$\begin{array}{l}\text { Presença } \\
\text { de mega- } \\
\text { cariócitos }\end{array}$} & \multirow{2}{*}{$\begin{array}{c}\text { Proliferação } \\
\text { de células } \\
\text { reticulares }\end{array}$} & \multirow{2}{*}{$\begin{array}{c}\text { Focos } \\
\text { de hema- } \\
\text { topoese }\end{array}$} & \multirow{2}{*}{$\begin{array}{c}\text { Lesões } \\
\text { vascu- } \\
\text { lares }\end{array}$} \\
\hline & & & & & $\begin{array}{l}\text { Presença } \\
\text { de sangue }\end{array}$ & $\begin{array}{l}\text { Leucoci- } \\
\text { tostase }\end{array}$ & & & & & & \\
\hline 07 & - & - & - & - & $+(+)$ & - & - & - & - & - & - & - \\
\hline 08 & + & - & - & - & ++ & ++ & - & - & - & - & - & - \\
\hline 09 & - & - & - & - & ++ & ++ & - & - & - & - & - & - \\
\hline 10 & - & - & - & - & ++ & ++ & - & + & - & - & - & - \\
\hline 11 & - & + & ++ & - & ++ & ++ & - & - & - & - & - & - \\
\hline 12 & - & - & $(+)$ & - & ++ & ++ & - & - & + & + & - & - \\
\hline 07A & + & - & - & - & +++ & + & - & - & - & - & - & - \\
\hline $08 \mathrm{~A}$ & - & - & + & + & ++ & ++ & - & - & - & - & - & - \\
\hline $09 \mathrm{~A}$ & - & - & - & - & + & + & ++ & $+(+)$ & - & ++ & + & - \\
\hline $10 \mathrm{~A}$ & + & + & - & ++ & ++ & + & ++ & ++ & - & - & - & ++ \\
\hline
\end{tabular}

No trabalho de Mebus et al. (1979) intitulado "Some characteristics of African swine fever viruses isolated from Brazil and the Dominican Republic", são fornecidos detalhes sobre a confirmação da peste suína africana no Brasil pelo isolamento do vírus em 31 de maio de 1978. Em outro trabalho (Mebus \& Dardiri 1979), intitulado "Additional characteristics of disease caused by the African swine fever viruses isolated from Brazil and the Dominican Republic", há mais dados sobre os estudos realizados em Plum Island.
Estudos complementares realizados de 2001 a 2003

Revisão histológica. A revisão histológica de todos os casos de PSA ou suspeitos de PSA, por nos estudados, revelou alterações características desta enfermidade apenas nos suínos do foco de Paracambi; em outros casos, tidos, inicialmente, como focos-satélites, o estudo histológico revelou lesões 

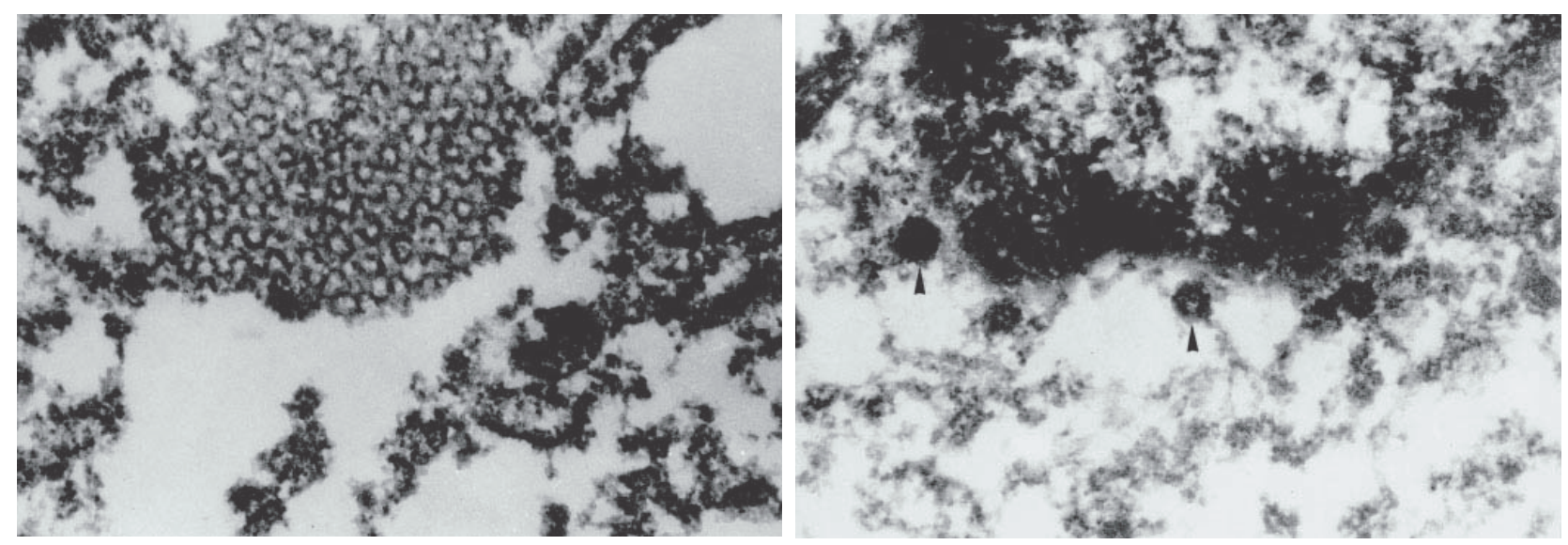

Fig. 16. Linfonodo. (A) Agrupamento de partículas no citoplasma de célula mononuclear sugestivas de formas imaturas do vírus da PSA. Acetato de uranila, citrato de chumbo. 48.000x; (B) Partículas exagonais (pontas de seta) próximas ao núcleo de célula mononuclear sugerem formas não-envelopadas do vírus da PSA. Acetato de uranila, citrato de chumbo. 48.000x

compatíveis com as de salmonelose, PSC ou de outras doenças.

Exames histopatológicos realizados no Onderstepoort Veterinary Research Institute. No Instituto de Onderstepoort foram feitas as seguintes observações sobre o material enviado: "As alterações histopatológicas nos pulmões, baço e nódulos linfáticos são compatíveis com o diagnóstico de peste suína africana subaguda a crônica. Não são compatíveis com PSA aguda, porque há pouca ou nenhuma cariorrexia, que é o característico para a PSA aguda. A pneumonia intersticial observada nos pulmões de todos os suínos, dos quais foi enviado tecido pulmonar, foi consistente e revelou as alterações descritas para PSA subaguda a crônica. A destruição das bainhas Schweigger-Seidel (trabéculas) nos baços examinados é fortemente sugestiva para PSA."

Estudo ultra-estrutural realizado na Universidade Federal de Pelotas. O exame de microscopia eletrônica do linfonodo (material incluído em parafina) do Suíno 10/78, revelou a presença de agregados de estruturas sugestivas de formas imaturas de vírus no citoplasma de células mononucleares; formas hexagonais com cerca $110 \mathrm{~nm}$, próximas ao núcleo de células mononucleares, sugerem partículas não-envelopadas do vírus da PSA (Fig.16A,B).

\section{DISCUSSÃO E CONCLUSÕES}

A suspeita inicial de que a enfermidade que estava ocorrendo no Sítio Floresta, Paracambi, RJ, era peste suína africana (PSA), deveu-se ao achado de hemorragias, por demais acentuadas, em especial nos linfonodos viscerais, de esplenomegalia e de pleuropneumonia. Tais lesões contrastavam muito com as verificadas em casos de peste suína clássica $(\mathrm{PSC})$ que, àquela época, ocorria no Estado do Rio de Janeiro e cursava com mínimas lesões macroscópicas, como costuma acontecer em regiões onde os suínos adquirem certa resistência ao vírus da PSC. No que se refere ao exame histopatológico inicial, também não ha- via vasculite e os infiltrados inflamatórios mononucleares no sistema nervoso central, lesão que afeta mais de $80 \%$ dos suínos com PSC. Em adição, a elevada virulência do agente (em comparação a do vírus da PSC, que ocorria no Rio de Janeiro àquela época), determinando grande mortandade em curto espaço de tempo, também indicava não tratar-se de PSC.

A verificação de que os suínos eram alimentados regularmente com restos de comida de restaurante, não-cozidos, oriundos de empresas aéreas que mantinham linhas para Portugal e Espanha, reforçou a suspeita. Os exames negativos para doenças bacterianas e para PSC corroboraram no estabelecimento do diagnóstico diferencial. Já a partir da reprodução de enfermidade muito semelhante à peste suína africana, em suínos vacinados contra a PSC, não havia mais dúvidas de que se tratava de PSA. Por fim, o isolamento do vírus da PSA realizado no Laboratório de Plum Island encarregou-se de confirmar o nosso diagnóstico. Recentemente, o estudo ultramicroscópico de fragmentos de material emblocado em parafina, oriundo de suíno do surto inicial, realizado mais para complementação, permitiu, inclusive, a visualização de partículas víricas fortemente sugestivas de PSA.

Os dados epidemiológicos, clínicos, anátomo e histopatológicos levantados no surto de Paracambi são semelhantes aos descritos na literatura pertinente sobre PSA(DeTray 1963, Neitz 1963, Bogado 1964, Maurer et al. 1964, Mitscherlich \& Wagner 1970, Hess et al. 1975, Hess 1981, Callis et al. 1982, Smith et al. 1983, Jubb et al. 1992, Plowright et al. 1994).

Após a ocorrência, em 1978, do surto de PSA descrito neste trabalho, 223 outros focos foram comunicados até o final de 1979; foram sacrificados, nesse período, 66.966 suínos, equivalendo a uma perda de mais de 44 milhões de dólares ao valor da época (Boletim Min. Agric. 1984). Com base nos dados fornecidos, é impossível concluir quantos focos teriam ocorrido em 1981, último ano após 1979 em que ainda foi relatada a doença no Brasil. Também não há informações referentes ao número de animais abatidos nesse período. O último caso foi relatado em 15 de novembro de 1981 e o Brasil foi declarado livre da PSA em 5 de dezembro de 1984 (Boletim Min. Agric. 1984). 
Para fins de diagnóstico da PSA foram processados no Laboratório de Peste Suína Africana do Departamento de Virologia do Instituto de Microbiologia, da Universidade Federal do Rio de Janeiro, no período entre 12 de junho de 1978 e 31 de dezembro de 1981, 54.002 amostras, sendo 9.148 amostras de órgãos ou sangue e 44.854 amostras de soro (Andrade et al. 1982). Essas amostras foram examinadas por 5 técnicas: hemadsorção em cultura de leucócitos (HAd), imunoflorescência em cortes de tecido (FATS), imunoflorescência em cultivo celular (FATCC), imuno-eletrosmoforese (IEOP) e imunoflorescência indireta (IIF). As amostras eram provenientes de 2.839 fazendas de todas Regiões do país (Norte, Nordeste, Centro-Oeste, Sudeste e Sul). De todas as amostras, $184(0,35 \%)$ foram positivas pela HAd, 166 $(0,32 \%)$ pela FATS, $4(0,008 \%)$ pela FATCC, $2.970(5,74 \%)$ pela IEOP e $102(0,19 \%)$ pela IIF. Esses autores não mencionam quais foram as provas positivas em cada um dos focos diagnosticados, nem os critérios utilizados em cada prova para o estabelecimento do diagnóstico da enfermidade. As datas de ocorrência dos focos e a distribuição geográfica dos mesmos tampouco foram informados.

Um importante aspecto a ser avaliado em relação às provas utilizadas para o diagnóstico de PSA diz respeito a sua especificidade; sabe-se que algumas dessas provas podem ser altamente sensíveis, mas com especificidade menor do que $100 \%$, ou seja, podem ocorrer falso-positivos, mesmo que num percentual muito baixo. A possibilidade de ocorrência de falsopositivos já fora levantada no próprio Boletim do Ministério da Agricultura em relação às provas de IEOP e IIF. Essas provas foram utilizadas para detectar anticorpos contra PSA em 49.643 soros coletados em frigoríficos em um trabalho realizado na Região Sul, em 1980, com intuito de verificar se a mesma estava livre de PSA. Os exames mostraram que, no Paraná, 283 (1\%) soros foram positivos para PSA pela IEOP e $80(0,3 \%)$ pela IFF (Lyra et al. 1983). Por outro lado, em exames sorológicos de 51.118 amostras de reprodutores coletadas em granjas, em 1981, foram encontrados $48(0,09 \%)$ suínos com anticorpos para PSA (Boletim Min.Agric. 1984). No referente aos resultados obtidos em 1980, no mesmo Boletim menciona-se a possibilidade de que se tratasse de infecções residuais, entretanto se considerou também que poderiam ser falso-positivos, visto que a sensibilidade e especificidade dessas provas permanecem desconhecidas quando utilizadas em grandes populações (Lyra et al. 1983). A evolução dos acontecimentos, tudo indica, confirmou esta última possibilidade, visto que, apesar dos resultados sorológicos positivos obtidos durante os anos de 1980 e 1981, e sem que tenham sido tomadas medidas para eliminar os suínos com anticorpos, o Brasil foi considerado livre da PSA em 1984 (Boletim Min.Agric. 1984).

De fato, até onde sabemos, não ocorreram casos de mortes em suínos com quadro clínico-patológico e epidemiológico compatível com o da PSA, antes ou depois do surto de Paracambi em 1978. Seria mesmo muito difícil que um quadro como o da PSA, dadas suas características, passasse despercebido de todos os patologistas veterinários. Com as provas de FATS e HAd, que determinam antígenos virais, tudo indica que também tenham ocorrido falso-positivos. A prova de HAd, embora reconhecida como de alta sensibilidade e tida como de alta especificidade para o diagnóstico de PSA (Sanchez-Vizcaino 1992), também pode resultar em falso-positivos, uma vez que outros vírus eventualmente apresentam capacidade de hemadsorção, entre eles orthomyxovirus, paramyxovirus e togavirus (Fenner et al. 1993). Falso-positivos também são descritos na prova de FATS como, por exemplo, para o diagnóstico de raiva, no qual a imunoflorescência direta é largamente utilizada; a correlação desta prova com as técnicas de isolamento viral é de 97-98\% (Fenner et al. 1993). Por fim, com o emprego da FATCC, a única das provas utilizadas que inclui o isolamento viral, foram encontradas somente 4 amostras positivas. Os autores acima mencionados não indicam a procedência das amostras que resultaram positivas por essa técnica, mas é provável de que sejam as provenientes do surto de Paracambi; por outro lado, não há referências na literatura brasileira sobre a existência e caracterização de outros isolamentos do vírus de PSA, a não ser do proveniente de Paracambi (Andrade 2002), denominado "Brazil isolate" (Mebus \& Dardiri 1979) ou Amostra-Brasil (Andrade at al. 1979, Andrade e Rodrigues 1982, Rodrigues et al. 1982).

A possibilidade de que tenham ocorrido diagnósticos falsamente positivos é referida, também, pelo próprio Ministério da Agricultura (Boletim Min.Agric. 1984), com base no fato de que, em Santa Catarina, as taxas de ataque do vírus oscilaram entre $72,64 \%$ e $0,18 \%$. Os autores do Boletim inclusive sugerem, em função desses números, que alguns focos não teriam sido causados pelo vírus da PSA, pois um mesmo agente não poderia apresentar taxas de ataque tão discrepantes.

Andrade et al. (1982) não fornecem a distribuição geográfica, nem a época em que ocorreram cada um dos focos de PSA relatados. Em uma publicação posterior, Rodrigues \& Andrade (1984) mencionam que, entre junho e outubro de 1978, foram diagnosticados focos nos Estados do Pará, Piauí, Pernambuco, Espírito Santo, Rio de Janeiro, São Paulo, Minas Gerais e Goiás, portanto apenas um mês depois da erupção do surto de Paracambi; nos parece impossível que o vírus tivesse se espalhado com essa rapidez para tantas áreas tão distantes entre si. Entre março e julho de 1979, a doença foi diagnosticada em Santa Catarina, São Paulo, Rio de Janeiro, Bahia e Minas Gerais e, em 1981, foram diagnosticados focos em Santa Catarina, Espírito Santo e Pernambuco. No Boletim do Ministério da Agricultura (1984) consta que 70\% dos focos ocorreram nas Regiões Sul e Sudeste, mas não se menciona especificamente em quais Estados, dessas ou de outras regiões, ocorreram os focos.

Entre as cepas de vírus da PSA isoladas em diversos países fora da África, há marcada variação na virulência, que pode determinar doença com cursos superagudo, agudo, subagudo, crônico ou inaparente (Hess 1981). O foco de Paracambi caracterizou-se por alta mortalidade e curso predominantemente subagudo, visto que em uma semana morreram $15 \%$ dos 1.000 suínos em risco. As lesões macroscópicas e histológicas, tanto nos suínos mortos no surto, quanto nos inoculados experimentalmente, foram características das infecções subagudas/crônicas. $\mathrm{O}$ estudo dessa amostra de vírus, realizado no Plum Island Animal Disease Center, determinou que se tratava de uma cepa de baixa virulência. Isto porque o vírus deste isolado -"Brazil isolate" (Mebus \& Dardiri 1979) ou Amostra-Brasil (Andrade et al. 1979, Andrade \& Rodrigues 1982, Rodrigues et al. 1982) - experimentalmente induziu a menor mortalidade (morreram 4 suínos de 9 inoculados), do que uma outra amostra, denominada 
Lisboa 60, que determinou mortalidade de 100\%(Mebus \& Dardiri 1979). Sabe-se que cepas pouco virulentas do vírus da PSA causam doença subaguda ou crônica (Mebus \& Dardiri 1979). Dos focos diagnosticados posteriormente no Brasil alguns teriam apresentado alta mortalidade, mas a maioria teria cursada com baixa mortalidade e "sinais clínicos inaparentes" (Lyra et al. 1983).

Segundo Andrade \& Rodrigues (1982), a ocorrência de formas aguda e crônica da doença e o aparecimento da PSA simultaneamente em vários Estados do País sugerem que a enfermidade já existisse antes do surto de Paracambi. Andrade \& Rodrigues (1982) levantam ainda a hipótese de que a enfermidade poderia ter sido disseminada pela vacina da PSC produzida com vírus inativado com cristal violeta, uma vez que o Laboratório da PSA teria detectado a presença do agente da PSA em "sementes de vírus" que seriam utilizadas no preparo dessas vacinas (Andrade 1978). Essa possibilidade nunca foi documentada cientificamente. Na realidade nada foi feito além de contaminar-se experimentalmente, em laboratório, a vacina da PSC com o vírus oriundo do foco de Paracambi e demonstrar que o vírus da PSA pode persistir por algum tempo nesse tipo de vacina (Rodrigues 1980), sem que, entretanto, tenha sido demonstrada a presença do vírus da PSA em qualquer vacina comercialmente vendida no Brasil. No trabalho de Rodrigues \& Andrade (1984) é repetida esta afirmação. No Boletim do Ministério da Agricultura (1984), denominado "Brasil, Livre da Peste Suína Africana”, não há mais qualquer referência a esse assunto.

Também foi levantada, por Andrade et al. (1979), a possibilidade de camundongos terem participado como vetores mecânicos na disseminação da PSA; embasaram essa hipótese na simples demonstração indireta da presença do vírus (prova de HAd) nas fezes de camundongos que ingeriram água experimentalmente contaminada com o vírus oriundo do foco de Paracambi, sem entretanto comprovar qualquer relação deste estudo com a enfermidade natural no Brasil.

A possibilidade de que formas crônicas ou inaparentes da doença estivessem presentes anteriormente no país também é sugerida por Hess (1981), com base na pressuposição de que a doença no "Hemisfério Oeste" (o autor utiliza o termo "Western Hemisphere", quando se refere aos surtos nas Américas do Sul e Central), teria se disseminado em muito pouco tempo. Esse autor, porém, não ventila a hipótese de que tenham ocorrido diagnósticos falsamente positivos. Com o objetivo de verificar a possibilidade de a PSA já estar presente no Brasil antes de 1978, soros de suínos, coletados e estocados desde 1976, portanto antes da ocorrência do foco de Paracambi foram analisados pela prova de IEOP. Alguns desses soros apresentaram anticorpos contra PSA, no entanto, esses resultados foram interpretados pelos autores, posteriormente, como falso-positivos (Boletim Min. Agric. 1984). De fato, parece extremamente improvável que a doença existisse antes de 1978 sem ser diagnosticada. Mesmo em relação à forma crônica da enfermidade é muito improvável que a PSA tenha passado despercebida, principalmente nas Regióes Sul e Sudeste, onde teriam ocorrido 70\% dos focos (Boletim Min. Agric. 1984). Isto porque, nessas regiões, já se praticava uma suinocultura empresarial, com tecnologia moderna e assistência técnica veterinária, comparável à suinocultura de alguns países desenvolvidos. Além disso, como foi constatado no foco descrito neste trabalho, cepas de baixa virulência podem causar doença com alta mortalidade quando introduzidas numa população altamente susceptível. Por outro lado, considerando-se o foco de Paracambi como o primário, não há explicação para a pretensa rápida disseminação da PSA após a ocorrência desse foco. Considerando a rapidez do diagnóstico e o sacrifício imediato dos suínos, que se iniciou 3 dias após o diagnóstico presuntivo e 10 dias após o início das mortes, é altamente improvável que uma doença que não existia anteriormente possa ter se disseminado de forma tão rápida, e logo a seguir, ter sido erradicada em período de tempo tão curto, em especial se levarmos em conta as hipóteses aventadas de disseminação através da vacina de PSC e ou de vetores mecânicos.

Uma terceira hipótese postulada para explicar a aparente rápida difusão da PSA no "Hemisfério Oeste" é a de que, talvez, o agente possuísse baixa virulência quando entrou no Brasil e que, em adição, a doença só teria sido diagnosticada após o vírus atingir concentração suficientemente elevada em alguns focos para causar uma elevada mortalidade (Hess 1981). Segundo este autor, o vírus poderia ter se espalhado antes do foco inicial, permanecendo em algumas áreas abaixo do nível de concentração requerida para produzir mortalidade elevada (Hess 1981). Esta hipótese pode ser descartada se considerarmos Paracambi como foco primário de PSA no Brasil, pois é evidente que a fonte de infecção foi a alimentação com restos de comida de aviões procedentes de Espanha e Portugal, onde a doença era endêmica.

$\mathrm{O}$ presente relato constitui a única descrição comprovada da ocorrência da PSA no Brasil com isolamento, identificação e confirmação da patogenicidade do vírus. Os trabalhos publicados posteriormente ao surto de Paracambi em 1978 não trazem qualquer informação sobre epidemiologia, sinais clínicos e patologia, bem como não se referem à virulência e à patogenicidade de vírus da PSA, pretensamente isolados no Brasil. Com base no que foi exposto, pode-se concluir, que, no Brasil, a PSA ocorreu e se manteve confinada ao foco de Paracambi. As razões mais prováveis de a enfermidade ter-se mantido restrita a esse foco, foram o diagnóstico precoce e a rápida adoção de eficientes medidas de controle das autoridades sanitárias; 0 abate dos suínos de Paracambi iniciou-se apenas 10 dias depois da primeira morte e no terceiro dia após o diagnóstico presuntivo.

Agradecimentos.- Ao Prof. Wilhelm O. Neitz, renomado pesquisador da África do Sul (in memoriam), pela orientação geral dada, ao Prof. Jefferson Andrade dos Santos (UFF) (in memoriam), pela opinião sobre os exames histopatológicos, à Dra. Charlotte H. Langenegger (IBA), pelos exames bacteriológicos, ao Prof. Royden C. Tustin, África do Sul, pela ajuda no encaminhamento do material ao Instituto de Pesquisa Veterinária de Onderstepoort, África do Sul, à Dra Mary-Lou Penrith pelas suas observações relativas aos achados histopatológicos, ao Prof. Anton Mayr (Univ. Munique), ao Dr. Nelson Morés (Embrapa-CNPSA), aos Profs Cláudio S.L. Barros e Eduardo F. Flores (UFSM), Hermann G. Schatzmayr (FIOCruz), David Driemeier e Paulo M. Roehe (UFRGS) pelas valiosas sugestões, e ao Prof. Cláudio Moraes Andrade, pelo fornecimento de informações e literatura.

\section{REFERÊNCIAS}

Andrade C.M. 1978. Detecção do vírus da Peste Suína Africana em sementes de vacinas Cristal Violeta; comunicação pessoal. (Cit. Andrade \& Rodrigues 1982)

Andrade C.M. 2002. Comunicação pessoal (Universidade Federal Rural do Rio de Janeiro).

Andrade C.M.\& Rodrigues L.C. 1982. Peste suína africana: estudo da resis- 
tência do vírus à ação do cristal violeta. Anais Microbiol., Rio de J., 27:177-191.

Andrade C.M., Rodrigues L.C \& Kobylinski E. M. 1979. Participação dos camundongos no ciclo epidemiológico da peste suína africana. Anais Microbiol., Rio de J., 24: 31-35.

Andrade C.M., Grüner A., Silva A.M., Marques C.J., Brandão C.T., Santangelo C., Maiolino C.C.C., Queiroz E.C., Amaral F.R., Lannes C.S., Teixeira L.M.W. \& Martins M.A. 1982. Peste suína africana no Brasil: 3 anos de laboratório. Anais Microbiol., Rio de J., 27: 205-220.

Bogado S.C. 1964. Peste suína africana. Estudos Técnicos, Serv.Inf.Agricola, Min. Agricultura, Rio de Janeiro. 39p.

Boletim do Ministério da Agricultura 1984. Brasil, Livre da Peste Suína Africana. Divisão de Combate e Profilaxia às Doenças, Secretaria de Defesa Sanitária Animal, Secretaria Nacional de Defesa Agropecuária, Min. Agricultura, Brasília. 63p.

Callis J.J., Dardiri A.H., Ferris D.H., Gay G.J., Mason J. \& Wilder F.W. 1982. Illustrated Manual for the Recognition and Diagnosis of Certain Animal Diseases. Mexico-United States Commission for the Prevention of Foot and Mouth Disease, Plum Island Animal Disease Center, New York.

DeTray D.E. 1963. African swine fever. Adv.Vet.Sci. 8:299-333.

Fenner F. J., Gibbs E. P. J., Murphy F. A., Rott R., Studdert M. J. \& White D. O. 1993. Veterinary Virology. 2nd ed. Academic Press, San Diego.

Hess W.R. 1981. African swine fever - a reassessment. Adv. Vet. Sci. Comp. Medicine 25:39-69.

Hess W.R., Pan I.C. \& DeBoer C.J. 1975. Peste suína africana, p.74-82. In: Depto Agric. Estados Unidos (ed.) Manual de Referências. Cursos de Doenças Exóticas, Centro de Doenças Animais de Plum Island, New York. (Tradução)

Jubb K.V.F., Kennedy P.C. \& Palmer N. 1992. Pathology of Domestic Animals. 2nd ed. Academic Press, New York.

Lyra T.M.P., Pavez M.M. \& Andrade C.M. 1983. Serological study of African swine fever in the pig population of southern Brazil. Agricultural Research Seminar on African Swine Fever, Sassari, Sardinia, Sept. 23-25, 1981, CRC/FAO, p.47-61.
Maurer F.D., Griesemer R.A. \& Jones T.C. 1964. African swine fever, p.187202. In: Dunne H.W. (ed.) Diseases of Swine. 2nd ed. Iowa State University Press, Ames.

Mebus C.A. \& Dardiri A.H. 1979. Additional characteristics of disease caused by the African swine fever viruses isolated from Brazil and the Dominican Republic. Proc. 83rd Annu. Meet. U. S. Anim. HIth Assoc., San Diego, California, p.227-239.

Mebus C.A., Dardiri A.H., Hamdy F.M., Ferris D.H., Hess W.R. \& Callis J.J. 1979. Some characteristics of African swine fever viruses isolated from Brazil and the Dominican Republic. Proc. 82nd Annu. Meet. U.S. Anim. Hlth Assoc., Buffalo, New York, 1978, p.232-236.

Mitscherlich E. \& Wagner K. 1970. Tropische Tierseuchen und ihre Bekämpfung. Afrikanische Schweinepest. 2. Aufl. Paul Parey, Berlin, p.344-354.

Neitz W.O. 1963. African swine fever, p.1-70, 221-226. In: FAO (ed.) Agricultural Studies no. 61, Emerging Diseases of Animals, Rome.

Plowright W., Thomson G.R. \& Neser J.A. 1994. African swine fever, p. 568599. In: Coetzer J.A.W., Thomson G.R. \& Tustin R.C. (ed.) Infectious Diseases of Livestock with Special Reference to Southern Africa. Vol. 1. Oxford Universtiy Press, Cape Town.

Rodrigues L.C. 1980. Peste suína africana. Estudo da resistência do vírus à ação do cristal violeta. Tese de Mestrado, Instituto de Microbiologia, Universidade Federal do Rio de Janeiro. 170p.

Rodrigues L.C. \& Andrade C.M. 1984. Análise epizootiológica da peste suína africana no Brasil (Breve Revisão). Revta Fac. Vet. Univ. Fed. Fluminense, Niterói, 1(2):7-13. [O mesmo artigo publicado em Arqs Flum. Med. Vet. 2(11):25-27, 1987]

Rodrigues L.C., Andrade C.M., Silva A. G. \& Baptista M. F. D. 1982. Observações ultramicroscópicas do vírus da peste suína africana em eritrócitos suínos. Anais Microbiol., Rio de J., 27: 221-226,

Sanchez-Vizcaino 1992. African Swine fever, p.228-236. In: Leman A.D., Straw B.E., Mengeling W.L., D'Allaire S. \& Taylor D.J. (ed.) Diseases of Swine. 7th ed. Iowa State University Press, Ames.

Smith H.A., Jones T.C. \& Hunt R.D. 1983 . Veterinary Pathology. 4th ed. Lea and Febiger, Philadelphia, p.463-466.

\section{Anexo}

\section{Protocolos dos achados anátomo e histopatológicos}

Suíno $7 / 78$

Achados de necropsia: pálpebras coladas e edemaciadas. Sangue com aspecto aquoso. Na parede do abdômen diversas petéquias e equimoses. Os linfonodos inguinais, parotidianos, mesentéricos referentes ao intestino grosso, ao corte, vermelhos na periferia ou quase totalmente avermelhados. Os pulmões na parte antero-inferior, com pleurite fibrinosa e parênquima hepatizado; lóbulos afastados por líquido avermelhado. No saco pericárdico, líquido seroso e gelatinoso. Epicárdio quase todo tomado por extensa hemorragia, que se estendia para dentro do miocárdio e, em parte, também ao endocárdio. Três áreas com diâmetro de 2-3 mm, arredondadas, de coloração azul enegrecida na superfície do baço. Na superfície e ao corte dos rins, grande quantidade de petéquias; ao corte muitas estrias avermelhadas e equimoses na pelve. Mucosa avermelhada na região fúndica do estômago. Serosa do íleo com múltiplas petéquias; serosa do cólon com extensas hemorragias difusas. Mucosa do cólon e reto difusamente avermelhada; a do reto também com petéquias.

Achados histopatológicos (SAP 22454): pulmão com pleurite fibrino-supurativa, broncopneumonia secundária mascarando a pneumonia intersticial. Hemorragias intra-alveolares, nos septos interlobulares e, em menor escala, na pleura. Moderada congestão difusa. Linfáticos dos septos repletos de sangue. Exsudato sero-fibrinoso com presença de alguns neutrófilos e macrófagos dentro de alvéolos, bronquíolos e bronquíolos terminais. Moderada pneumonia intersticial. Leucocitostase (mista com predomínio de macrófagos e com presença de linfócitos e neutrófilos) em veias e capilares. Fígado com leucocitostase mista moderada, predominando macrófagos. Focos e áreas de necrose coagulativa bem delimitados com infiltração por macrófagos e neutrófilos com localização paracentral. Baço com leve congestão e moderada depleção linfóide. Linfonodos com presença de sangue nos seios subcapsulares e, em menor escala, nos seios medulares (drenagem). Intestino com congestão e hemorragias leves a moderadas na porção superior da mucosa, associadas a leve infiltração inflamatória mista; congestão e hemorragias acentuadas na submucosa e em parte na muscular; derrame sero-sangüinolento ou serofibrinoso na serosa. Rim com congestão e hemorragias; drenagem de sangue na pelve. Leve leucocitostase em veias.

\section{Suíno $8 / 78$}

Achados de necropsia: edema gelatinoso na parte frontal da cabeç e nas regiões submandibular e retrofaríngea; na face interna do membro anterior esquerdo e na área da escápula, hemorragias subcutâneas e entre os feixes musculares; edema e hemorragias subcutâneas na parte inferior dos membros posteriores. Alguns linfonodos retrofaríngeos, ao corte, com focos e áreas de diferentes tonalidades de vermelho. Os pulmões com acentuado edema, grupos de lóbulos separados por líquido gelatinoso; pericardite fibrinosa em organização incipiente afetando pequena área do epi e pericárdio; no pericárdio área com edema hemorrágico. Na cavidade abdominal aproximadamente meio litro de líquido avermelhado com coágulo de fibrina. Linfonodos hepáticos, tanto na superfície como ao 
corte, de coloração vermelho-escura; parede da vesícula biliar acentuadamente espessada por edema hemorrágico. Baço muito aumentado, com bordos arredondados e numerosas hemorragias subcapsulares de alguns milímetros de diâmetro. Na superfície de ambos os rins, grande quantidade de petéquias e equimoses com diâmetro de 2-3 mm; grande sufusões na superfície de corte dos rins. Poucas petéquias na mucosa da bexiga. Leve congestão na mucosa da região fúndica do estômago.

Achados histopatológicos (SAP 22455): leve a moderada pneumonia intersticial; áreas com edema alveolar e edema sero-fibrinoso em septos interlobulares. Fígado com moderada leucitostase. Baço com moderada a acentuada congestão difusa. Hemorragias na cápsula e no hilo. Trabéculas infiltradas por células inflamatórias. Linfonodos com presença de sangue nos seios subcapsulares; medula congesta com grande quantidade de leucócitos. Derrames sero-fibrinosos ou sero-hemorrágicos pericapsulares. Trombo linfático com localização peri-capsular. Rim com congestão e hemorragias no hilo. Coração com hemorragias, congestão e derrame sero-fibrinoso intersticiais, em grau discreto. Músculo estriado com acentuada necrose, extensas hemorragias e infiltrados inflamatórios na parede de arteríola (vasculite).

\section{Suíno $9 / 78$}

Achados de necropsia: pele e mucosas pálidas. Sangue com aspecto aquoso. Linfonodos submandibulares e retrofaríngeos aumentados e ao corte com áreas e focos de diferentes tonalidades de vermelho. Pericárdio aderido ao epicárdio. Pulmôes com acentuado edema, pesados e úmidos ao corte. Superfície de corte do fígado levemente alaranjada. Baço muito aumentado em volume, sem hemorragias. Superfície dos rins com raras petéquias. Toda serosa do intestino, especialmente do intestino delgado, semeada de petéquias. Parede do estômago muito espessada (pouco menos que $1 \mathrm{~cm}$ ) por edema hemorrágico na região fúndica; no centro desta região, mucosa com foco de necrose difteróide (aprox. $3 \mathrm{~cm}$ ).

Achados histopatológicos (SAP 22456): moderada a acentuada pneumonia intersticial; infiltração inflamatória mista na mucosa de brônquios (subepitelial e entre as glândulas); presença de macrófagos na luz de alguns bronquíolos; pleura espessada e com área de infiltração inflamatória mononuclear (pleurite crônica focal). Fígado com moderada a acentuada leucocitostase. Leve a moderada infiltração inflamatória mista (células mononucleares e polimorfonucleares com presença de eosinófilos) entre os lóbulos e nos espaços-porta. Leve infiltração por células inflamatórias predominantemente mononucleares em torno das veias centro-lobulares, acompanhada de leve fibrose. Pequenos focos de necrose coagulativa (lesão discreta). Presença de pigmento amarelado sob forma de grumos nos sinusóides ou dentro de macrófagos. Leves infiltrados inflamatórios na cápsula hepática. Baço com moderada congestão. Degeneração e necrose na cápsula e nas trabéculas com infiltrados inflamatórios mistos. Serosite fibrino-neutrofilica. Na polpa vermelha leucocitostase, predominantemente por macrófagos. Necrose com figuras de cariorrexia e picnose em alguns folículos. Linfonodos com presença de hemácias misturadas a grande quantidade de leucócitos degenerados ou necróticos nos seios sub-capsulares e na medula. Submucosa do estômago espessada por exsudato fibrinoso com presença de numerosos leucócitos e dilatação de vasos linfáticos que contêm grande quantidade de detritos celulares (leucócitos necróticos) misturados à fibrina (trombos linfáticos); extensas áreas de necrose com zona de demarcação na base da mucosa; infiltrados inflamatórios e edema na muscular e serosa (polisserosite); perivasculite e vasculite (infiltrados leucocitários com predominância de macrófagos na parede de veias e ao seu redor); trombos na veias da submucosa. Na muscular derrame sero-fibrinoso com infiltrados inflamatórios mistos, principalmente ao redor de vasos e dilatação de linfáticos. No intestino grosso infiltrados inflamatórios mistos na serosa (serosite); na mucosa infiltrados inflamatórios mistos com alguns eosinófilos. Rim com áreas de infiltração inflamatória mista na proximidade do hilo. Coração com leve epicardite crônica (espessamento por fibrose).

\section{Suíno $10 / 78$}

Achados de necropsia: extensas hemorragias subfasciais nos músculos internos da coxa (adutor, semimembranoso); psoas com extensas hemorragias no permeio. Linfonodos pré-crural esquerdo, da base do coração, do hilo do fígado e o gástrico, aumentados, vermelhos na superfície e ao corte, lembrando hematomas; linfonodo hepático com $6 \times 3 \times 3 \mathrm{~cm}$. Os outros linfonodos aumentados e com áreas e focos de diferentes tonalidades de vermelho; os linfonodos lombo-aórticos, ao corte, com o mesmo aspecto, por vezes lembrando hematomas. Pulmões com edema (brônquios com espuma), pesados e, ao corte, úmidos; lobos apicais hepatizados; excesso de líquido com aspecto citrino no saco pericárdico e na cavidade pleural. Epicárdio com sufusões e equimoses, especialmente nas aurículas. Vesícula biliar com edema e hemorragias na parede. Baço moderadamente aumentado de volume, com hemorragias sub-capsulares múltiplas confluentes. Rins na superfície com algumas petéquias e equimoses de até $2 \mathrm{~mm}$. Mucosa gástrica na região fúndica com algumas áreas hemorrágicas e pequenos focos de necrose difteróide. Pequeno foco de necrose difteróide na válvula íleo-cecal. Meninges congestas.

Achados histopatológicos (SAP 22457): broncopneumonia fibrinosupurativa necrotizante, com grande quantidade de colônias bacterianas; pneumonia intersticial de difícil quantificação em função do mascaramento dado pela infecção secundária; pleurite sero-fibrinosa; septos interlobulares bastante espessados por exsudato sero-fibrinoso, às vezes por infiltrados inflamatórios mistos; nessas áreas, os linfáticos dilatados estão preenchidos pelo exsudato anteriormente referido ou por hemácias, ou ainda estão trombosados. Fígado com moderada proliferação de células de Kupffer sob forma de focos aleatórios no parênquima, bem como nos espaços-porta e nos septos interlobulares; leucocitostase; leve a moderada infiltração inflamatória mista nos espaços-porta e nos septos interlobulares; focos de fibrose sub-capsulares com leve retração em conexão com os septos; leve aumento do tecido conjuntivo nos septos. Baço com áreas de necrose coagulativa sub-capsulares, leve congestão e focos inflamatórios mistos na parede de grandes vasos e nas trabéculas; presença de numerosos megacariócitos e leve a moderada depleção linfóide; discretos focos inflamatórios mistos na cápsula. Linfonodos com seios marginais e na medula preenchidos por hemácias, entremeadas com células inflamatórias mistas, em parte degeneradas ou necrosadas (com cariorrexia); algumas áreas de fibrose nos seios marginais. Mucosa do intestino delgado com leves infiltrados inflamatórios mistos e presença de eosinófilos. Intestino grosso com acentuado espessamento da submucosa por derrame sero-fibrinoso em organização entremeado por células inflamatórias mononucleares e polimorfonucleares; dilatação de vasos linfáticos, contendo grande quantidade de leucócitos com ou sem fibrina; trombose incipiente; mucosa levemente infiltrada por células inflamatórias, sobretudo plasmócitos; leve depleção linfóide nas placas de Peyer; marcada infiltração inflamatória mista nas adjacências; na mucosa, focos de inflamação difteróide com fibrose na base. Rim com discretos infiltrados inflamatórios subepiteliais e leve congestão na pelve. Sistema nervoso central com leve a moderada congestão e discreta infiltração inflamatória mononuclear das meninges; leucocitostase. Músculo estriado com grandes hemorragias, degeneração e necrose acompanhadas de infiltração inflamatória mista por entre as fibras; calcificação distrófica de fibras necrosadas.

\section{Suíno 11/78}

Achados de necropsia: linfonodos submaxilares muito aumentados de volume; ao corte com áreas e focos de diferentes tonalidades de vermelho. Pleurite fibrinosa do lado direito. Pulmões com moderado edema, lobos apicais com pequenas áreas hepatizadas, grande quantidade de líquido citrino na pleura, no saco pericárdico e na cavidade abdominal. Linfonodos gastroesplênicos e do hilo do fígado externamente avermelhados; ao corte com áreas e focos de diferentes tonalidades de vermelho. Vesícula biliar com hemorragias na serosa. Baço pouco aumentado, com múltiplas hemorragias sub-capsulares. Algumas petéquias na superfície dos rins (diâmetro de 2-3 $\mathrm{mm})$.

Achados histopatológicos (SAP 22458): leve pneumonia intersticial; vasculite e perivasculite; leves infiltrados sub-pleurais difusos predominantemente mononucleares; infiltrados inflamatórios mistos na mucosa dos brônquios e bronquíolos; áreas de broncopneumonia exsudativa e de necrose coagulativa na pleura com reação inflamatória mista. Fígado com leve leucocitostase e dilatação dos sinusóides; edema dos espaços de Disse; intensa infiltração leucocitária nos espaços-porta e nos septos interlobulares com parte destas células em degeneração; leve fibrose e ativação das células endoteliais de alguns vasos, preenchidos por eosinófilos. Baço com grandes áreas de necrose coagulativa do tipo fibrinóide; necrose fibrinóide da parede de artérias e grande quantidade de megacariócitos e de megacarioblastos; derrame sero-fibrinoso por vezes acompanhado por infiltrados inflamatóri- 
os mistos na cápsula, por fora dela, e nas trabéculas; moderada depleção linfóide. Linfonodos com grande quantidade de hemácias acompanhadas por numerosos leucócitos em cariorrexia e picnose nos seios sub-capsulares e na medula; leucocitostase em grandes vasos linfáticos do hilo e inflamação da cápsula; moderada necrose coagulativa de folículos (cariorrexia e picnose). Rim com congestão e hemorragias na junção córtico-medular e alguns discretos infiltrados inflamatórios mistos.

\section{Suíno 12/78 (sacrificado em estado agônico)}

Achados de necropsia: Pulmões com edema moderado. Baço um pouco aumentado. Rins na superfície com petéquias e equimoses múltiplas. Peritonite fibrinosa acentuada. Mucosa da região fúndica do estômago acentuadamente congesta. Parede do cólon espessada e com extensas hemorragias.

Achados histopatológicos (SAP 22459): moderada a acentuada pneumonia intersticial com marcada infiltração de macrófagos; espessamento da pleura por fibrose. Infiltrados inflamatórios predominantemente mononucleares na submucosa de brônquios. Fígado, com leve leucocitostase, tecido conjuntivo intersticial levemente aumentado, com leve infiltrado inflamatório misto; focos de proliferação das células de Kupffer no parênquima, nos septos interlobulares e nos espaços-porta. Baço com capsulite sero-fibrinosa em organização; grande quantidade de megacariócitos na polpa vermelha e moderada a acentuada depleção linfóide; leve congestão e infiltrados inflamatórios mistos nas trabéculas Linfonodos com seios marginais preenchidos com hemácias e grande quantidade de leucócitos; proliferação das células reticulares e discretos focos de necrose nos folículos; presença de megacariócitos e megacarioblastos. Rim com focos de hemorragias no córtex e na medula. Coração com leve espessamento fibroso do epicárdio, sem inflamação ativa.

Suíno 7A/78 (inoculado em 12.5 .78 com suspensão de baço do Suíno 7/ 78 ; encontrado morto em 23.5.78, às $16: 30 \mathrm{~h}$ )

Achados de necropsia: pele e mucosas pálidas. Linfonodos superficiais e internos, com exceção dos mesentéricos e, em parte, dos mediastinais, aumentados de volume e de cor vermelho-enegrecida, externamente e ao corte, parecendo hematomas. Nos músculos da região posterior e do flanco, presença de poucas hemorragias pequenas. Nos músculos da região posterior esquerda (local da inoculação) equimoses e áreas esbranquiçadas duras. Equimoses na língua e epiglote. Pulmões com leve edema e com alguns lóbulos tomados por hemorragia, bem como por algumas equimoses subpleurais; área hemorrágica de $1 \mathrm{~cm}$ de diâmetro na pleura parietal. Pericárdio com equimoses e sufusões. Epicárdio, principalmente o da aurícula esquerda e do ventrículo direito, tomado por equimoses e sufusões. Endocárdio do ventrículo esquerdo com sufusões. Hemorragias na parede da vesícula biliar. Linfonodo do hilo do fígado muito aumentado e enegrecido na superfície e ao corte. Linfonodo gástrico aumentado e enegrecido. Pequena hemorragia subcapsular em um rim, e extensas hemorragias subcapsulares em outro; na superfície, bem como ao corte, grande quantidade de petéquias; pelve renal preenchida por sangue; um ureter com parede espessada, e vermelho- enegrecida. Mucosa da bexiga quase toda vermelho-enegrecida (hemorragia). Serosa da parte fúndica do estômago com petéquias e sufusões; mucosa com pequena área hemorrágica. Intestino delgado, principalmente o jejuno, com conteúdo avermelhado e coágulos sangüíneos ricos em fibrina, sob forma de flocos e filamentos; serosa com pequenas equimoses. Ceco e parte inicial do cólon com mucosa coberta por induto mucoso avermelhado. Mucosas congestas com algumas pequenas ulcerações de aproximadamente $1 \mathrm{~mm}$, às vezes com bordo avermelhado. Mucosa do reto com petéquias e equimoses; na luz alguns pequenos coágulos sangüíneos.

Achados histopatológicos (SAP 22264). pneumonia intersticial, infiltrados inflamatórios de intensidade leve a moderada nas paredes alveolares; leve fibrose nos septos com infiltrados predominantemente mononucleares; acúmulo de fibrina com ou sem hemácias nos alvéolos e bronquíolos terminais; fibrina com leucócitos necróticos (em cariorrexia) nos bronquíolos e brônquios. Áreas com edema intra-alveolar e outras com hemorragias intra-alveolares e intra-bronquiolares. Na pleura fibrose com infiltrados linfocitários focais. Fígado com muitos corpúsculos de choque nos vasos; leve a moderada vacuolização centro-lobular com microfocos de necrose de hepatócitos; picnose, fragmentação, vacuolização e tumefação de células circulantes (leucócitos). Baço com microfocos de necrose coagulativa. Necrose de trabéculas e de leucócitos circulantes. Leves infiltrados inflamatórios nas trabéculas. Linfonodos com acentuada drenagem de sangue nos seios subcapsulares e da medula. Derrame fibrinoso peri-capsular com presença de alguns polimorfonucleares. Pequena quantidade de polimorfonucleares nos seios subcapsulares. Focos submiliares de necrose coagulativa na superfície da mucosa do estômago. Pequenos focos de necrose e hemorragias com presença de numerosos plasmócitos na mucosa do intestino delgado.

Suíno 8A/78 (inoculado em 12.5 .78 com suspensão de baço do Suíno 8/ 78; encontrado morto em 22.5.78, às 8:00h)

Achados de necropsia: linfonodos superficiais com acentuada congestão e poucas hemorragias. Pulmões com moderado edema e grandes hemorragias nos septos interlobulares, com muita espuma ligeiramente avermelhada na traquéia e nos brônquios. Parede da vesícula biliar com acentuado edema. Baço ligeiramente aumentado de volume. Intestino delgado com poucas hemorragias puntiformes na mucosa. Intestino grosso com congestão da mucosa e presença de pequenos focos craterifomes de necrose no ceco e reto. Linfonodos gástricos e portais aumentados, com aspecto de coágulo; linfonodos mesentéricos congestos e com algumas hemorragias. Rins ligeiramente congestos e com poucas equimoses. Encéfalo com hemorragias nas meninges.

Achados histopatológicos (SAP 22463): no pulmão necrose e depleção dos folículos linfóides peribronquiais; dentro dos alvéolos muito sangue com transudato sero-fibrinoso; acentuado derrame seroso ou sero-fibrinoso, com presença de hemácias, interlobular, com drenagem dos mesmos pelos linfáticos interlobulares e fibrose incipiente; pneumonia intersticial de intensidade leve a moderada com presença de muitos leucócitos degenerados ou necróticos; lesões vasculares sob forma de necrose e degeneração das células endoteliais e infiltrados inflamatórios na parede de veias; infiltrado inflamatório misto na adventícia; exsudato sero-fibrinoso com alguns leucócitos dentro de brônquios e moderado derrame sero-fibrinoso na pleura. No figado leucocitostase com alterações regressivas nos leucócitos circulantes; microfocos de necrose de hepatócitos; picnose, fragmentação, vacuolização e tumefação de células circulantes; exsudato predominantemente fibrinoso entre a parede da vesícula biliar e o parênquima hepático; no interstício do fígado septos interlobulares muito espessados por fibrina entremeada por leucócitos, parte em degeneração e necrose; tumefação endotelial com muitos corpúsculos de choque. Baço não examinado. Linfonodo com drenagem de fluido sero-fibrinoso e/ou serosangüinolento rico em leucócitos em diferentes fases de degeneração e necrose. Folículos com necrose coagulativa (picnose e cariorrexia) e/ou depleção. Estômago com derrame fibrinoso e sangue na luz; áreas de necrose e de hemorragia na superficie da mucosa, por vezes associadas a leves infiltrados inflamatórios. Intestino grosso com infiltrados mistos por entre as criptas (difusamente na mucosa) e na submucosa. Necrose linfóide nas placas de Peyer.

Suíno 9A/78 (inoculado em 12.5 .78 com suspensão de baço do Suíno 9/ 78; sacrificado em 27.5.78 por determinação das autoridades sanitárias)

Achados de necropsia: sufusões no epicárdio, ao longo do sulco átrio-ventricular. Todos os linfonodos, especialmente os gástricos e o do hilo do fígado, aumentados de volume, porém sem congestão e hemorragias. Baço bem aumentado de volume e com coloração vermelho-escura.

Achados histopatológicos (SAP 22466): moderada pneumonia intersticial predominantemente mononuclear, com presença de numerosos eosinófilos nos septos interlobulares; fibrose com infiltrados inflamatórios mistos, principalmente nas proximidades do hilo pulmonar e hipertrofia dos músculos de Reisseisen. Presença de células com citoplasma volumoso e micro-vacuolizado na parede de alvéolos. Na pleura arteríolas de pequeno calibre com proliferação endotelial, desorganização das fibras musculares com espessamento eosinofílico da parede; células endoteliais volumosas, hipercromáticas e com conformação um tanto bizarra; mitose do endotélio; leve proliferação inflamatória mononuclear na adventícia. No fígado numerosos focos aleatórios de células de Kupffer e de hematopoese extramedular (hemácias nucleadas). Baço com periesplenite mononuclear; proliferação endotelial de vasos arteriais e infiltrados inflamatórios mistos nas trabéculas com pequena quantidade de megacariócitos; proliferação de células reticulares e congestão leves. Nos linfonodos, presença de hemácias, células leucocitárias, exsudato de 
fibrina e fibrose nos seios marginais; leve a acentuada hiperplasia das células reticulares com presença de numerosos eosinófilos; hematopoese extramedular. Rim com acúmulo de filtrado dentro de glomérulos e de túbulos com leve "degeneração em gotas hialinas", necrose do epitélio tubular e infiltrado focal de células mononucleares no córtex; ativação das células da cápsula de Bowman, espessamento de alças glomerulares, com presença de eosinófilos. Hematopoese extramedular na gordura do hilo renal. Congestão e hemorragias nas meninges; alteração vascular nos vasos das meninges lembrando às das arteríolas do pulmão.

Suíno 10A/78 (inoculado em 12.5 .78 com suspensão de baço do Suíno 10/78; sacrificado em 27.5.78 por determinação das autoridades sanitárias)

Achados de necropsia: linfonodos do hilo do fígado ligeiramente aumentados e, ao corte, avermelhados na periferia. Baço um pouco aumentado e de coloração vermelho-escura. Rins de coloração vermelho-escura e na superfície com numerosas petéquias. Na mucosa do cólon e cecum presença de pequenas elevações crateriformes. Meninges com forte congestão.

Achados histopatológicos (SAP 22467): pneumonia intersticial variando de intensidade de área para área, entre discreta a moderada; espessa-

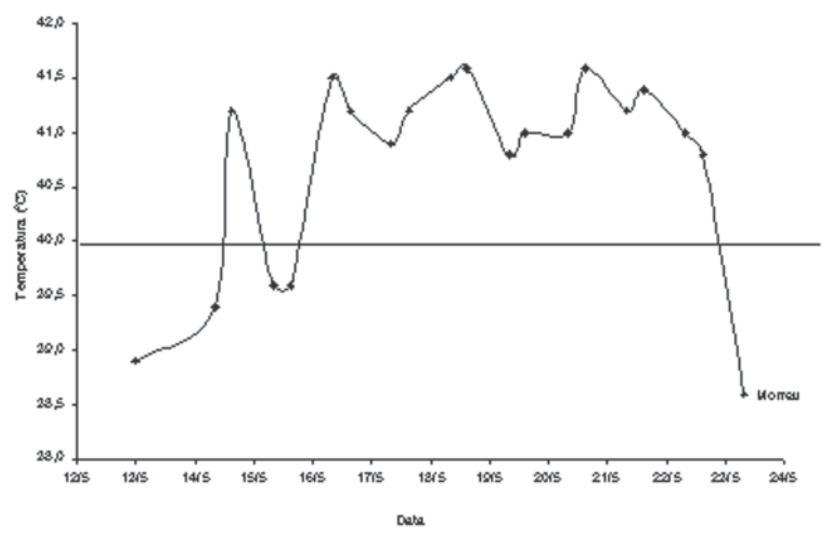

Fig. 9. Evolução da temperatura corporal do Suíno 7A/78 após a inoculação intramuscular, em 12.5.1978, com suspensão de baço do Suíno 7/78 (Caso natural). A partir de 18.5.78, o animal teve anorexia; a partir de 21.5.78, apresentava-se em decúbito lateral; em 22.5.78, anêmico, com fezes sangüinolentas e hematúria; em 24.5.78, morreu à tarde.

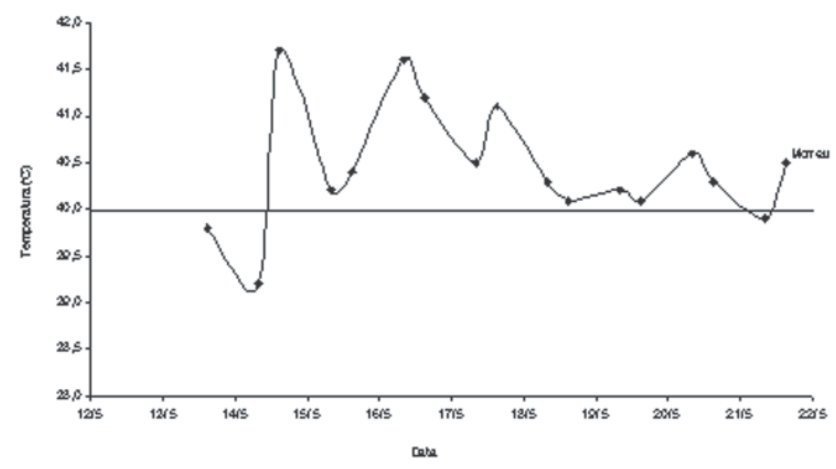

Fig. 10. Evolução da temperatura corporal do Suíno 8A/78 após a inoculação intramuscular, em 12.5.1978, com suspensão de baço do Suíno 8/78 (Caso natural). A partir de 16.5.78, com anorexia; em 22.5.78, morreu pela manhã. mento da parede de algumas arteríolas, com aspecto fibrinóide e desorganização da estrutura, congestão, hiperplasia endotelial e perivasculite; macrófagos presentes no lúmen desses vasos. Discreto a leve espessamento dos septos por fibrose e infiltrado inflamatório leucocitário. Fígado com leve vacuolização difusa do citoplasma dos hepatócitos; leve aumento do tecido conjuntivo nos septos com infiltrados mononucleares. Baço com depleção do tecido linfóide, congestão e leve hiperplasia das células endoteliais dos vasos, e infiltrados inflamatórios leucocitários (mistos) nas trabéculas e na cápsula; grande vaso com endarterite mista. Linfonodos com acentuada fibrose entremeada por células inflamatórias mononucleares e por eosinófilos nos seios sub-capsulares e medulares; moderada depleção linfóide e grande quantidade de eosinófilos no restante do parênquima; moderada hiperplasia e ativação do endotélio com infiltração fibrinosa na parede vascular; infiltrados inflamatórios mistos nos septos; em um linfonodo grande quantidade de hemácias e fibrina entremeadas por leucócitos (mono e polimorfonucleares) nos seios sub-capsulares; capsulite e pericapsulite; leve hiperplasia difusa de células reticulares. Infiltrados linfo-histiocitários na mucosa com pequenas erosões na mucosa no intestino grosso. Placas de Peyer com numerosos corpúsculos de Russel.

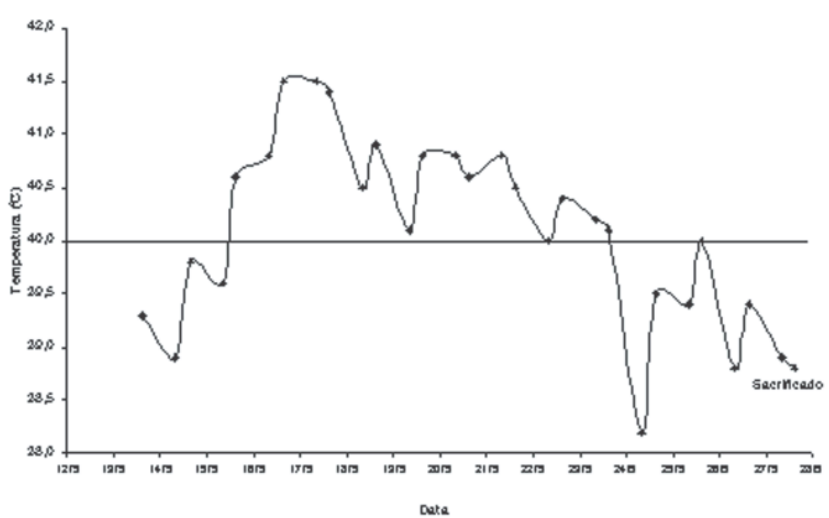

Fig. 11. Evolução da temperatura corporal do Suíno 9A/78 após a inoculação intramuscular, em 12.5.78, com suspensão de baço do Suíno 9/78 (Caso natural). De 16 a 19.5.78, com anorexia; de 20 a 24.5.78. com apetite quase normal; em 25 e 26.5.78, com acentuada diminuição do apetite; em 27.5.78, sacrificado pela manhã.

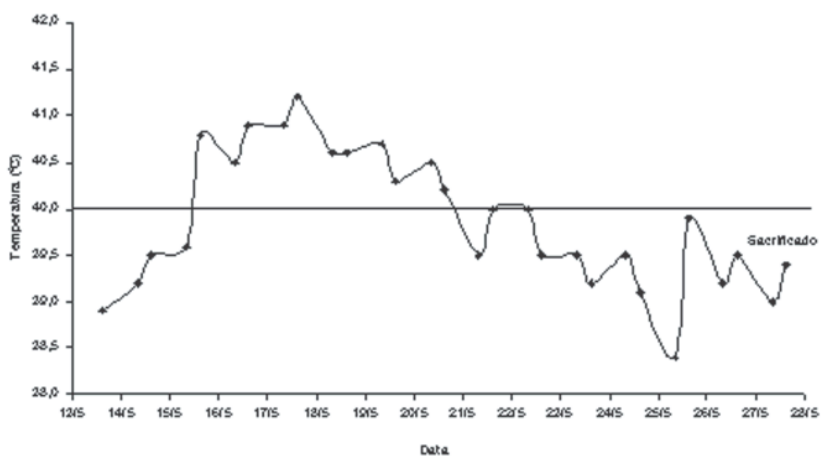

Fig. 12. Evolução da temperatura corporal do Suíno 10A/78 após a inoculação intramuscular, em 12.5.1978, com suspensão de baço do Suíno 10/78 (Caso natural). A partir de 18.5.78, com anorexia; a partir de 22.5.78, apresentava-se em decúbito lateral, com orelhas e focinho avermelhados; em 24.5.78, com a superfície do corpo fria; em 27.5.78, sacrificado à tarde. 


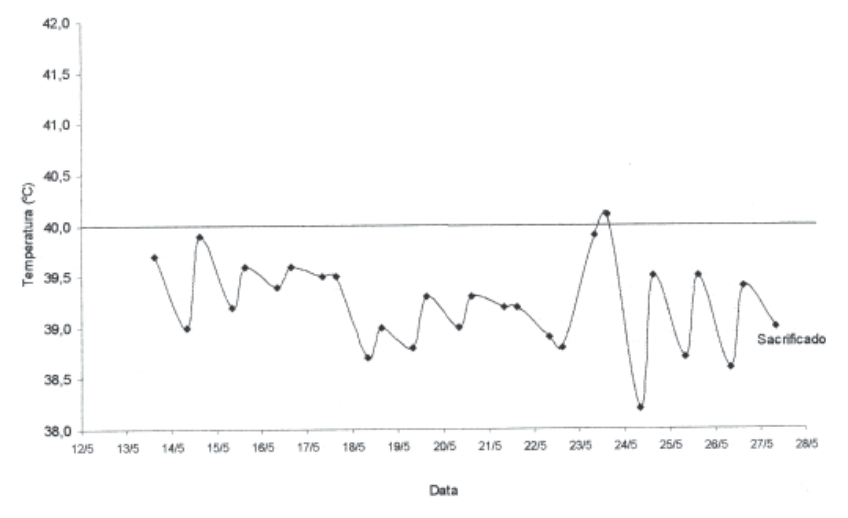

Fig. 13. Evolução da temperatura corporal do Suíno-Controle (não-inoculado). Sempre comeu bem; em 27.5 .78 foi sacrificado pela manhã.

Fig. 14. Carta do Chefe do Laboratório de Diagnóstico do Plum Island Animal Disease Center com a confirmação do diagnóstico de peste suína africana no foco de Paracambi, RJ.

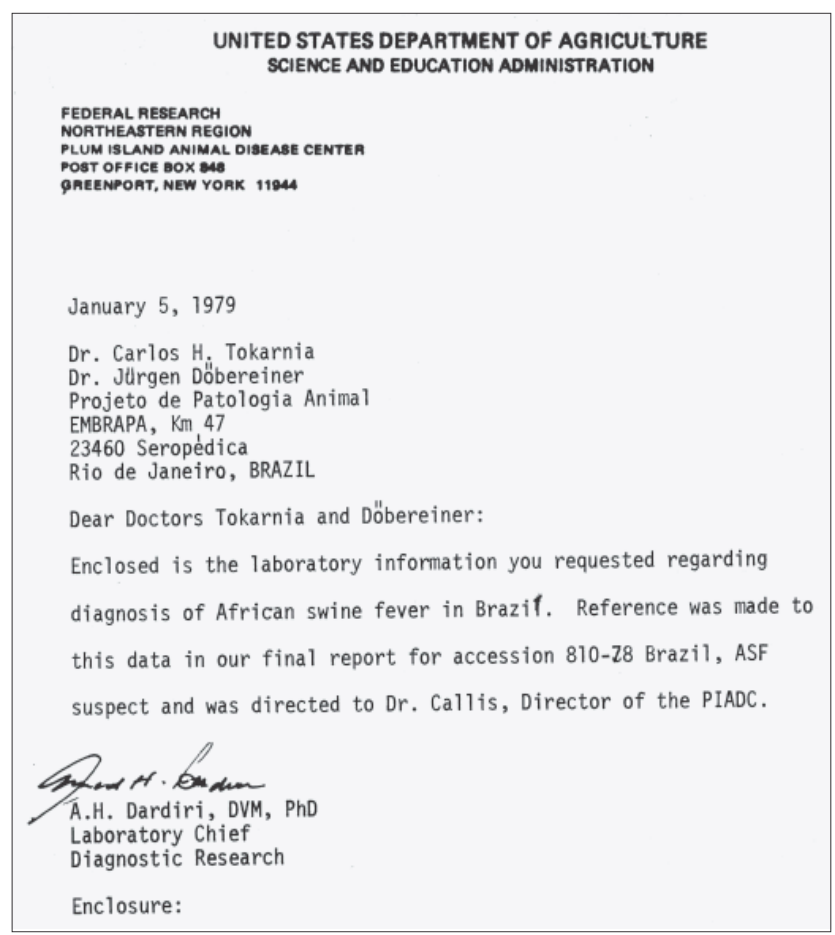

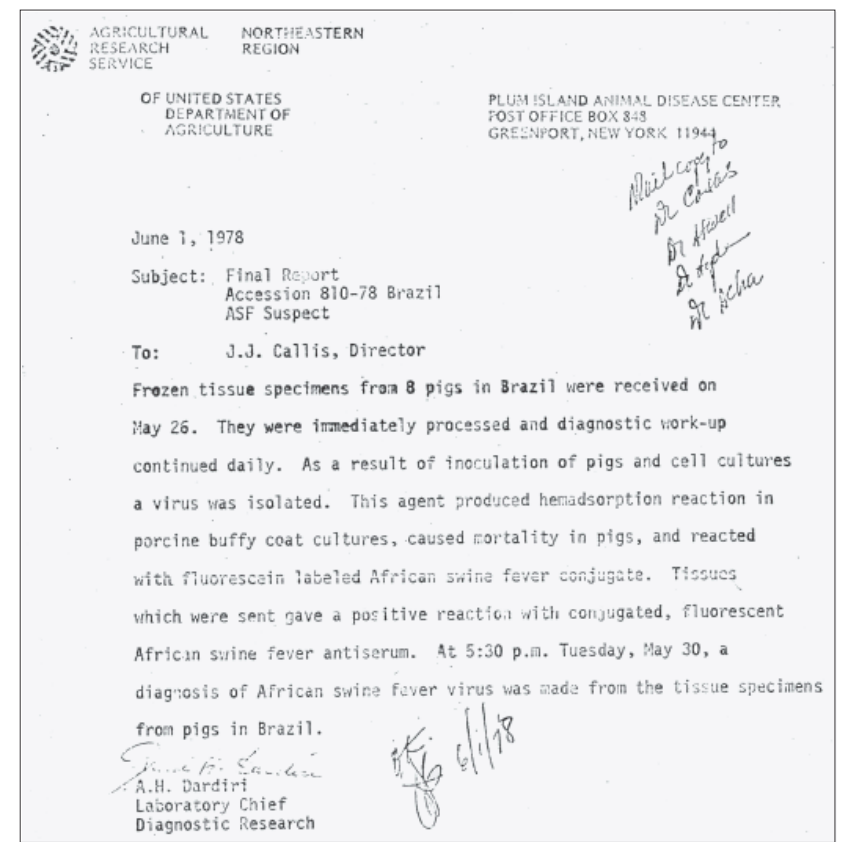

\begin{tabular}{|c|c|c|c|}
\hline \multicolumn{4}{|c|}{ January 1979} \\
\hline $\begin{array}{l}\text { Specimen } \\
\text { Number }\end{array}$ & I.D. Number & Direct FA & HAD \\
\hline 1 & $17 / 78$ & Negative & Negative \\
\hline 2 & $8 / 78$ & Negative & Negative \\
\hline 3 & $7 / 78$ & Negative & Negative \\
\hline 4 & $16 / 78$ & Negative & Negative \\
\hline 5 & $15 / 78$ & Negative & Negative \\
\hline 6 & $13 / 78$ & Negative & Negative \\
\hline 7 & $18 / 78$ & Negative & Positive \\
\hline 8 & $7 A / 78$ & Negative & Positive \\
\hline 9 & $8 A / 78$ & Negative & Positive \\
\hline
\end{tabular}

A pool of tissue suspension of nine specimens was inoculated into two pigs with two pigs used as contact controls. All four pigs developed fever and one of two in each group died and had ASF lesions. ASF virus was isolated from each of the four pigs. In addition, two hog cholera immune pigs were inoculated with the ASF Brazilian isolate. Both pigs exhibited fever and viremia and one died. ASF virus was reisolated.

A.H. Dardir1

Laboratory Chief

Diagnostic Research

Fig. 15. Carta do Chefe do Laboratório de Diagnóstico do Plum Island Animal Disease Center fornecendo detalhes dos exames realizados com o material de Paracambi, RJ. 